\title{
The oxytocin receptor signalling system and breast cancer: a critical review
}

\author{
Huiping Liu $\mathbb{D}^{1} \cdot$ Christian W. Gruber ${ }^{2} \cdot$ Paul F. Alewood ${ }^{1} \cdot$ Andreas Möller $\mathbb{D}^{3} \cdot$ Markus Muttenthaler $\mathbb{D}^{1,4}$
}

Received: 29 April 2020 / Revised: 21 July 2020 / Accepted: 29 July 2020 / Published online: 11 August 2020

(c) The Author(s) 2020. This article is published with open access

\begin{abstract}
Breast cancer is making up one-quarter of all new female cancer cases diagnosed worldwide. Breast cancer surgeries, radiation therapies, cytotoxic chemotherapies and targeted therapies have made significant progress and play a dominant role in breast cancer patient management. However, many challenges remain, including resistance to systemic therapies, tumour recurrence and metastasis. The cyclic neuropeptide oxytocin (OT) elicits a plethora of biological responses via the oxytocin receptor (OTR) in both the central and peripheral nervous system, including social bonding, stress, maternal behaviour, sexual activity, uterus contraction, milk ejection and cancer. As a typical member of the G protein-coupled receptor family, OTR represents also an intriguing target for cancer therapy. There is emerging evidence that OTR plays a role in breast cancer development and progression, and several breast cancer cell lines express OTR. However, despite supporting evidence that OT lowers breast cancer risks, its mechanistic role in breast cancer development and the related signalling pathways are not fully understood. Here, we review the current knowledge of the OT/OTR signalling system in healthy breast tissue as well as in breast cancer, and discuss OTR as a potential therapeutic target for breast cancer management.
\end{abstract}

\section{Introduction}

Breast cancer is the most commonly diagnosed cancer in women, making up one-quarter of all new female cancer cases diagnosed worldwide [1]. Current treatments for breast cancer include surgery, systematic radio- and chemotherapy, hormonal therapy, targeted therapy (such as HER2- and EGFR-targeted therapy) and immunotherapy [2]. Progress in clinical management strategies and early detection through increased awareness and use of mammography has improved survival for female breast cancer patients, with 5-year relative survival rates of $89 \%$ [2].

Markus Muttenthaler

markus.muttenthaler@univie.ac.at

1 Institute for Molecular Bioscience, The University of Queensland, Brisbane, QLD 4072, Australia

2 Center for Physiology and Pharmacology, Medical University of Vienna, 1090 Vienna, Austria

3 Tumour Microenvironment Laboratory, QIMR Berghofer Medical Research Institute, Herston QLD 4006, Australia

4 Institute of Biological Chemistry, Faculty of Chemistry, University of Vienna, 1090 Vienna, Austria
However, for metastatic breast cancer, the 5-year relative survival rate remains low at $27 \%$ [3].

The oxytocin receptor (OTR) is a $\mathrm{G}$ protein-coupled receptor (GPCR) of the class A/rhodopsin family and a key receptor system for birth, breastfeeding and social interactions, particularly for mother-child bonding [4, 5]. It is activated by its endogenous ligand oxytocin (OT), a cyclic nonapeptide (CYIQNCPLG) with a disulfide bond between the two cysteine residues and a C-terminal amide. The OT/ OTR signalling system is an evolutionary ancient (600-700 million years [6]) and widely distributed signalling system that regulates a multitude of functions in a wide range of different cell types $[5,7,8]$. It is utilised by many cancer types [9-11], including small-cell lung carcinoma [12], trophoblast and choriocarcinoma [13], osteosarcoma [14], Kaposi's sarcoma [15], neuroblastoma and glioblastoma [16], endometrium adenocarcinoma [17], leiomyoma [18], ovarian carcinoma [19], prostate carcinoma [20, 21] and osteosarcoma [22]. The connection between breast cancer and the OT/OTR signalling system emerged from epidemiologic studies indicating that childbearing and breastfeeding reduce the risk of breast cancer development $[23,24]$. Dysregulation of OT/OTR in breast tumour tissues could also be linked with the immune escape mechanism of the cancer cells considering its functions in the immune 
system $[25,26]$. A range of in vitro and in vivo studies support this OT/OTR involvement in breast cancer, which is the focus of this review. We furthermore review OTR's signalling pathways to clarify its regulatory role in cell growth and OTR's therapeutic potential for breast cancer management.

\section{OT in human breast development and tumorigenesis}

The mammary gland is one of the few organs that undergoes most of its development postnatally through distinct stages (embryonic, pubertal growth, pregnancy, lactation, and involution stages) and breast development continues throughout life [27]. Mammary cells undergo tightly regulated changes in growth, differentiation, invasion, and apoptosis, and dysregulation of these processes can be a contributor to breast tumorigenesis [28]. Breast cancer risk is affected by a variety of factors, including reproductive history and lifetime hormonal exposure, which also influences the course of the disease [29]. Oestrogen, progesterone and prolactin are well-studied hormonal regulators of mammary gland development [27, 29, 30]; less is known however about the regulatory roles of OT/OTR during breast development and tumorigenesis.

\section{OT and breast development}

The effects of OT on non-lactating mammary gland remains poorly explored since most studies have focused on OT's role during pregnancy and lactation [31]. Breast development culminates during pregnancy and the lactation cycle when the mammary gland undergoes complete remodelling, including maturation into a functional milk-secretory organ. This is followed by regression as weaning commences, which is completed after involution during which the breast regresses to a resting state [32]. Normally, mammary glands of lactating rats enter involution following the cessation of suckling, however, OT administration in lactating rats after removal of their litters (which mimics the weaning process) results in a delay of involution [33], an effect also observed in other studies [34-36]. These data suggest a role of OT in maintaining and modulating the status of the mammary gland.

OT is also produced, and secreted by myoepithelial and epithelial cells within normal and neoplastic breast [37], supporting the existence of local autocrine/paracrine loops that could influence cell growth, and differentiation of the mammary gland during breast development. In fact, OT can affect breast cell growth and differentiation both in vitro and in vivo [38-40]. For example, exposure of myoepithelial cells to OT results in the enhancement of myoepithelial cell differentiation and proliferation, enhancing the effect of mammotrophic hormones in non-lactating mouse mammary gland, with a less pronounced effect in luminal breast epithelial cells [38]. OT is also required for postpartum mammary proliferation, supported by the observation that mammary epithelial cells in OT-deficient mice fail to proliferate within $12 \mathrm{~h}$ after parturition, while $\sim 2 \%$ of the alveolar cells in wild-type animals incorporated DNA and proliferated. Furthermore, the continuous suckling of pups leads to lobulo-alveolar expansion in control animals but not in OT-deficient animals [39].

\section{Protective effects of OT against breast cancer development}

OT's preventive potential against breast cancer was initially discussed and reviewed in the 1990s, based on the hypothesis that OT production from nipple stimulation leads to myoepithelial cell contractions that help to relieve acinar gland distension and to remove carcinogenic substances such as superoxide free radicals from the breast, thereby reducing the risk to develop breast cancer [41].

Childbearing and breastfeeding, where OT plays a crucial role, are known protective factors against breast cancer $[23,24]$. Childless women (the nulliparous populations) have a higher risk for breast cancer development than those who have given birth to one or more children [41-43]. Prolonged breastfeeding, usually involving multiple children, correlates with a progressive decrease in breast cancer risk [23, 44, 45]. In the collaborative reanalysis of individual data from 47 epidemiological studies in 30 countries, including 50,302 women with and 96,973 women without breast cancer, the relative risk to develop the disease decreased by $4 \%$ for every 12 months of breastfeeding, and by $7 \%$ for each birth in women who never breastfed [24]. In a study from Sri Lanka, which included 100 cases of breast cancer and 203 controls, the risk was reduced even more profoundly, with 12-23 months, 24-35 months and 36-47 months of breastfeeding reducing breast cancer risk by $66 \%, 87 \%$ and $94 \%$, respectively (compared to 0-11 months of breastfeeding) [46]. The 'non-sexual' breast may carry a breast cancer risk similar to that of the "nonbreastfeeding' breast [47]. In age-matched nulliparous women, breast cancer incidence was lower in the sexually active group than in the celibate group [43], which also aligns with increased OT plasma levels in sexually aroused women [48].

Physical exercise is another protective factor [49-51] that correlates with increased OT levels $[52,53]$ with an average risk reduction is $25 \%$ among physically active women compared to the least active women [54]. Physical exercise also reduces symptoms in cancer patients (including breast cancer patients) and improves their physical and 
psychosocial state during and after treatments [55]. A mouse xenograft model study demonstrated that OT can mediate the beneficial effects of physical exercise on breast cancer growth. Both exercise and OT administration decreased tumour volume and weight, and OT plasma concentration in the tumour and exercise group was more than 10-fold higher than in the tumour control group (tumour without exercise) [56]. OT levels in the pituitary and blood also increased in a rat breast cancer model induced by $\mathrm{N}$-methyl-nitrosourea (NMU)-treatment due to inhibition of insulin-regulated aminopeptidase (an oxytocinase) and decrease of catabolism of OT in the hypothalamus [57]. This is consistent with a human study, which observed higher OT plasma levels in breast cancer patients $(n=40)$ than in healthy individuals [58]. Higher OT plasma levels, however, do not mean higher OT levels in breast cancer tissue. OT levels in breast tumour tissue is $\sim 2$-fold lower than in normal breast tissue [59], which may be related to increased activity of the oxytocinase in breast cancer tissues [60]. A reduction of OT in the mammary tissue may partially account for mammary tumorigenesis, while the increases in the pituitary release of OT may serve as a compensatory mechanism to suppress the proliferation of breast cancer [26]. Thus, an increase in OT levels might serve as a potential biomarker for breast cancer development or progression.

The exact mechanisms of these protective effects and the interplay with other factors in these physiological situations remain to be fully elucidated. However, OT is associated with these effects due to its increasing levels in plasma during the first to third trimester of pregnancy [61], breastfeeding [62], sexual response [48] and physical exercise $[52,53]$. OT is also a potent anti-inflammatory agent that can attenuate oxidative stress and inflammatory cytokine release in colonic injury [63], inflammation of the renal parenchyma [64], and vascular diseases [65-67]. Since oxidative stress and inflammation are two crucial contributors to many diseases, including breast cancer [26], the anti-inflammatory effects of OT should be taken into consideration for its potential to reduce the risk for breast cancer development and disease progression. While the preventive effects of OT look promising, its exact role in reducing breast cancer risks requires further investigation.

\section{OTR expression and function in the breast}

OTR's function of mediating the effects of OT in the normal female breast is well understood. OT and OTR not only regulate lactation but also control the organogenetic process and the histogenesis of different lesions in the breast [68], for instance, OTR overexpression can induce abnormal mammary gland development [69]. There is emerging evidence that OTR also plays a role in breast cancer development, however, how receptor expression and signal transduction change when breast cancer initiates remains unclear.

\section{OTR in the healthy breast}

OTR is endogenously expressed in most cells at low levels (often $<100 \mathrm{fmol} / \mathrm{mg}$ protein) [70], but it is most abundant in the female breast [10]. In normal non-lactating and nonneoplastic human breast specimens, OTR is located on the cell membrane and in the cytoplasm of cells of the basal cell layer, which mainly consists of myoepithelial cells and undifferentiated cells, with very few epithelial cells being OTR positive (Fig. 1a) [68]. The basic components of a mature mammary gland are the alveoli lined with milksecreting cuboidal cells and surrounded by myoepithelial cells. These alveoli form groups known as lobules. Each lobule has a lactiferous duct that connects to the nipple (Fig. 1a) [71]. The primary function of OTR in the breast is to mediate milk ejection during breastfeeding. This has been confirmed in both OTR-deficient [72] and OT-deficient [73] mice, which fail to nurse their offspring due to impaired milk ejection and maternal nurturing. OTR expression remains up-regulated from pregnancy to lactation in mammary gland in rats [74]. Both mammary gland OTR expression and OT plasma level rise in response to breastfeeding, an effect that persists during the lactation period $[62,75]$. The contractility response of the myoepithelial cells is mainly mediated by OTR coupling to $\mathrm{G} \alpha_{\mathrm{q} / 11}$ under the stimulation of OT (Fig. 1b) [76, 77], which increases the intracellular calcium $\left(\left[\mathrm{Ca}^{2+}\right]_{i}\right)$ concentration by releasing $\mathrm{Ca}^{2+}$ from internal stores, as well as by mobilising extracellular pools via the opening of voltage- and agonistsensitive $\mathrm{Ca}^{2+}$ channels $[78,79]$. Consequently, the alveolar milk is shifted to the cisternal space, drained into the lobule lumen towards the nipple through the lactiferous duct [80]. OTR and protein kinase C (PKC) activation can activate the MAPK cascade resulting in prostaglandin production, which contributes to contraction and milk ejection [81, 82]. Moreover, OTR can also activate the RhoA/Rho-kinase cascade resulting in increased myosin light-chain kinase (MLCK) phosphorylation responsible for OT-induced cell contractility [83]. Apart from $\mathrm{G}_{\mathrm{q} / 11}$ signalling, part of the OTR response in the uterus is also linked to OTR coupling to $\mathrm{G} \alpha_{\mathrm{i}}$ [84], which is, however, less understood. Meanwhile, co-stimulation of the ACII-cAMP-PKA signalling cascade via $\mathrm{G \alpha}_{\mathrm{i}}$-derived $\beta \gamma$-dimers can counterbalance the $\mathrm{G} \alpha_{\mathrm{q} / 11^{-}}$ dependent effect and self-limit the OT-induced cell contractile response [85]. In the central nervous system, $\mathrm{G} \alpha_{\mathrm{q} / 11}$ and $\beta \gamma$ subunits play a dominant role in burst firing evoked by applied OT or by suckling in the milk-ejection reflex [86]. 


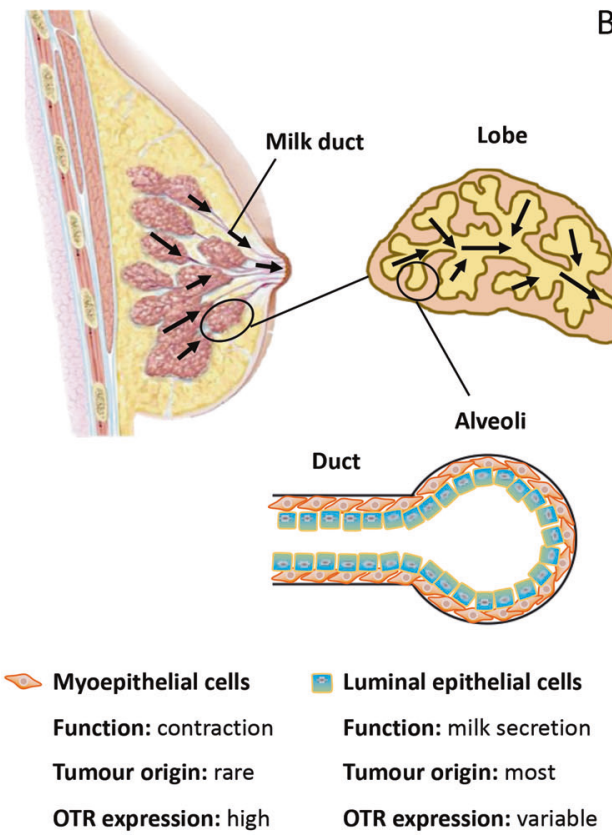

Fig. 1 Oxytocin receptor in the female breast and its function in mediating milk letdown. a Basic components of a mature female mammary gland, with black arrows indicating milk flow. b. Signal transduction mechanism of OTR during lactation. OTR coupling to $\mathrm{G} \alpha_{\mathrm{q} / 11}$ under the stimulation of OT activates phospholipase C (PLC), which hydrolyses phosphatidylinositol biphosphate $\left(\mathrm{PIP}_{2}\right)$ to diacylglycerol (DAG) and inositol triphosphate $\left(\mathrm{IP}_{3}\right)$. DAG activates protein kinase $\mathrm{C}(\mathrm{PKC})$, while $\mathrm{IP}_{3}$ causes release of $\mathrm{Ca}^{2+}$ from the sarcoplasmic reticulum $\mathrm{Ca}^{2+}$ store. $\mathrm{G}_{\mathrm{q} / 11}$ also causes activation of voltage- and agonist-regulated $\mathrm{Ca}^{2+}$ channels, which allow $\mathrm{Ca}^{2+}$ influx

\section{OTR in breast cancer}

OTR expression and function in breast cancer is unexpected because human breast cancers are typically of epithelial, not myoepithelial origin (Fig. 1a) [87]. OTR is widely present in breast cancer cell lines, benign sclerosing adenosis and breast carcinomas [68, 88-90]. So far there are more than ten human breast cell lines known to have positive OTR expression either at the protein or mRNA level, including MCF-7, T47D, Hs578T, SK-BR-3, MDA-MB4353, BT474, BT549, BT20, ZR75, MDA-MB-231, MDA-MB-361, MDA-MB-468, as well as non-cancer stromal cell lines, including HMEC (human dermal microvascular endothelial cells), and B-TEC (tumour-associated endothelial cells purified from human breast carcinomas) [37, 40, 59, 88, 9194]. However, not all breast cancer tissues have detectable OTR expression, either at the mRNA level (positive in 20 out of $27,74 \%$ [68]) or protein level (positive in 7 out of 13 , $54 \%$ [68], 52 out of $57,91 \%$ [88], and 15 out of $19,79 \%$ [90]). So far there exists only one study indicating that OTR expression in tumour tissues is lower ( $>11$-fold at mRNA level and $>2$-fold at the protein level, $n=4$ ) than in normal contralateral breast samples from the same individual. The authors of this study stated that a reduction of OTR expression in breast cancer could be effective in promoting cancer progression [58].

No conclusive data exist yet for the diagnostic or prognostic value of OTR for breast cancer development or progression. In a canine mammary tumour study, OTR levels were higher in benign tumour tissues $(6.42 \pm 0.27$, $n=19)$ than in malignant tumour tissues $(5.75 \pm 0.26, n=$ 24, $P=0.08$ ), higher in malignant oestrogen receptor $\alpha$ $(\mathrm{ER} \alpha)$-positive tumour tissues $(6.27 \pm 0.21, n=14)$ than in ER $\alpha$-negative tumour tissues $(5.54 \pm 0.37, n=10, P=$ $0.06)$, and significantly higher in histological grade I (6.2 \pm $0.29, n=10)$ and II $(6 \pm 0.53, n=7)$ lesions than in grade III $(4 \pm 0, n=3, P<0.05)$ lesions [95]. In humans, very few studies have indicated a relationship between OTR expression and other clinical variables (such as tumour size, biomarkers, metastasis or histological grade), except that OTR is more likely to be correlated with oestrogen receptorpositive $\left(\mathrm{ER}^{+}\right)$breast tumours. For example, there were more samples diffusely expressing OTR (diffusely expressing was defined as that $>80 \%$ cells were stained by IHC detection) in $\mathrm{ER}^{+}$samples (18 out of $32 \mathrm{ER}^{+}$patients) than in ER-negative $\left(\mathrm{ER}^{-}\right)$patients (7 out of $19 \mathrm{ER}^{-}$patients) 
[88], with OTR gene expression being 8.6-fold higher in breast tumour tissues of $\mathrm{ER}^{+}$patients $(n=27)$ than $\mathrm{ER}^{-}$ patients $(n=10)$ [58].

There is little knowledge about the regulation of the OT/ OTR system during breast cancer development. Given the evidence gathered to date and the discussion above, understanding the OT/OTR system in breast cancer is of major biological and clinical significance.

\section{Preclinical studies of OTR ligands in breast cancer}

The protective effects of OT along with OTR presence in breast cancer cell lines and tissues led to the investigation of OT and OT analogues (atosiban, vasopressin, desmopressin) in several breast cancer models. The study details and therapeutic implications for breast cancer management are summarised in the following paragraphs.

\section{In vivo studies}

Targeting OTR for breast tumour growth inhibition and tumour reduction was studied in vivo in mouse mammary carcinoma TS/A [96], rat carcinoma D-R3230AC [96] and mouse MC4-L2 carcinoma [56, 97] (Table 1). In all of these studies, OT had profound effects on tumour growth inhibition [56, 68, 96, 97] or even tumour reduction [97], and OT was a key mediator for the observed beneficial effects of physical activity in breast cancer [56]. Of note, in the mouse MC4-L2 carcinoma xenograft model [56, 97], doses of 1,000-fold difference (from 0.03 to $30 \mu \mathrm{g} / \mathrm{kg}$ ) were used. Although there are no specific guidelines with regards to the dose and dosing interval for long-term use of OT in cancer research, the published doses of the peptide need to be critically considered for any further studies defining tolerable and therapeutic doses.

The OT analogue atosiban (AT) also reduced breast cancer tumour growth in the TS/A (mouse) and DR3230AC (rat) xenograft models [96]. AT used to be considered an OTR antagonist, but was later characterised as a biased OTR ligand that blocks the $\mathrm{G} \alpha_{\mathrm{q} / 11}$ pathway and activates the $\mathrm{G} \alpha_{\mathrm{i} 3}$ pathway $[98,99]$. By contrast, AT had no effects on tumour reduction in the mouse MC4-L2 carcinoma models, where OT reduced tumour growth [56, 97].

${ }^{111}$ In-labelled OT-like tracer ${ }^{111}$ In-DOTA-LVT $\left({ }^{111} \mathrm{In}\right.$ 1,4,7,10-tetraazacyclododecane-N,N',N",N"'-tetraacetic acid-Lys ${ }^{8}$-vasotocin) [100], and its improved version ${ }^{111} \mathrm{In}$ DOTA-dLVT ( ${ }^{111}$ In-1,4,7,10-tetraazacyclododecane-N,N', N",N"'-tetraacetic acid-Lys ${ }^{8}$-deamino-vasotocin) [101] were developed to visualise OTR-expressing breast tumours and to study tracer/ligand uptake in mouse xenograft

Table 1 Overview of in vivo studies using OT analogues for breast cancer inhibition.

\begin{tabular}{|c|c|c|c|c|}
\hline Species & Cell lines & Treatment & Tumour reduction & Reference \\
\hline $\begin{array}{l}\text { Mouse } \\
(\mathrm{BALB} / \mathrm{c})\end{array}$ & TS/A & $\begin{array}{l}\text { OT pellet, steady } 10^{-8} \mathrm{M}^{\mathrm{a}}(\sim 0.58 \mu \mathrm{g} / \mathrm{kg}), 21 \text { days } \\
\text { AT o.p., steady } 10^{-9} \mathrm{M}(\sim 0.058 \mu \mathrm{g} / \mathrm{kg}) \text { and } 10^{-8} \mathrm{M}^{\mathrm{a}}(\sim 0.58 \mu \mathrm{g} / \mathrm{kg}) \text {, } \\
14 \text { days }\end{array}$ & $\begin{array}{l}50 \% \text { b } \\
65 \%, 72 \%\end{array}$ & $\begin{array}{l}{[68,96]} \\
{[96]}\end{array}$ \\
\hline $\begin{array}{l}\text { Rat } \\
\text { (Fisher) }\end{array}$ & $\begin{array}{l}\text { D- } \\
\text { R3230AC }\end{array}$ & $\begin{array}{l}\text { OT o.p., steady } 10^{-8} \mathrm{M}^{\mathrm{a}}(\sim 0.64 \mu \mathrm{g} / \mathrm{kg}), 14 \text { days } \\
\text { AT o.p., steady } 10^{-9} \mathrm{M}(\sim 0.058 \mu \mathrm{g} / \mathrm{kg}) \text { and } 10^{-8} \mathrm{M}^{\mathrm{a}}(\sim 0.58 \mu \mathrm{g} / \mathrm{kg}) \text {, } \\
14 \text { days }\end{array}$ & $\begin{array}{l}74 \% \\
66 \%, 90 \%\end{array}$ & [96] \\
\hline $\begin{array}{l}\text { Mouse } \\
(\mathrm{BALB} / \mathrm{c})\end{array}$ & MC4-L2 & $\begin{array}{l}\text { OT, } 0.03 \mu \mathrm{g} / \mathrm{kg} \text {, daily i.p., } 14 \text { days } \\
\text { AT, } 1.5 \mu \mathrm{g} / \mathrm{kg} \text {, daily i.p., } 14 \text { days }\end{array}$ & $\begin{array}{l}82 \% \\
\text { No effect }\end{array}$ & {$[56]$} \\
\hline $\begin{array}{l}\text { Mouse } \\
(\mathrm{BALB} / \mathrm{c})\end{array}$ & MC4-L2 & $\begin{array}{l}\text { OT, } 30 \mathrm{nmol} / \mathrm{kg}(\sim 30 \mu \mathrm{g} / \mathrm{kg}) \text {, daily i.p., } 14 \text { days } \\
\text { AT, } 1.5 \mu \mathrm{g} / \mathrm{kg} \text {, daily i.p., } 14 \text { days }\end{array}$ & $\begin{array}{l}49 \% \text { volume }^{\mathrm{b}} \\
\text { No effect }\end{array}$ & [97] \\
\hline $\begin{array}{l}\text { Athymic } \\
\text { nude mice }\end{array}$ & $\begin{array}{l}\text { MDA- } \\
\text { MB-231 }\end{array}$ & $\begin{array}{l}{\left[\mathrm{V}^{4} \mathrm{Q}^{5}\right] \text {-desmopressin, } 0.3 \mu \mathrm{g} / \mathrm{kg} \text { i.v. thrice weekly, in combination or }} \\
\text { not with weekly cycles of paclitaxel }(10 \mathrm{mg} / \mathrm{kg} \text { i.p. })\end{array}$ & $\begin{array}{l}\text { Inhibition of tumour growth and } \\
\text { invasion, and enhanced }\end{array}$ & {$[152]^{\mathrm{d}}$} \\
\hline $\begin{array}{l}\text { Mouse } \\
(\text { BALB/c) }\end{array}$ & F3II & $\begin{array}{l}{\left[\mathrm{V}^{4} \mathrm{Q}^{5}\right] \text { Desmopressin, } 0.3 \mu \mathrm{g} / \mathrm{kg} \text { i.v. thrice weekly, in combination or }} \\
\text { not with weekly cycles of carmustine }(20 \mathrm{mg} / \mathrm{kg} \text { i.p. })\end{array}$ & chemotherapy effects & \\
\hline
\end{tabular}

$O T$ oxytocin, molecular weight $=1007.2 \mathrm{~g} / \mathrm{mol} ; A T$ atosiban, molecular weight $=994.2 \mathrm{~g} / \mathrm{mol} ;$ mouse blood volume $\sim 58 \mathrm{~mL} / \mathrm{kg}, \mathrm{rat} \mathrm{blood}$ volume $\sim 64 \mathrm{~mL} / \mathrm{kg}$; o.p. osmotic pump, i.p. intraperitoneal injection, i.v. intravenous injection, alkylating drug carmustine and antimitotic agent paclitaxel are clinical drugs for cancer cytotoxic therapy.

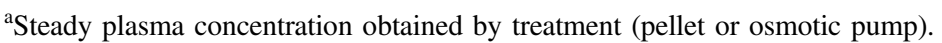

${ }^{b}$ No exact number shown, calculated according to data or figure of publication.

${ }^{c}$ Percentage of tumour volume increase slower than controls, calculated from tumour volume increase compared with treatment day 1 , tumour volume increase was $200 \%$ in controls, $52 \%$ in OT treated, $20 \%$ and $67 \%$ in AT $10^{-9} \mathrm{M}$ and $10^{-8} \mathrm{M}$ treated animals, all other inhibitory responses were compared with control group.

${ }^{\mathrm{d}}$ Main receptor investigated was $\mathrm{V}_{2} \mathrm{R}$, not OTR. 
models. The tumour/blood, tumour/liver and tumour/kidney uptake ratios of ${ }^{111}$ In-DOTA-dLVT were $7.58,1.42$, and 0.06 , respectively, in the preclinical study of animals bearing TS/A tumours [101]. The reason for high ligand uptake in the kidney and liver is that OT metabolism occurs mainly in these organs [102]. These studies are important as they support the therapeutic potential of OTR in breast cancer management, in terms of reduction and imaging/ diagnosis of OTR-positive breast tumours.

While these findings are promising, it should be noted that none of the in vivo studies used xenograft models with human breast cancer cell lines. To improve the translational perspectives, in vivo studies targeting OTR in human breast cancer xenograft models are required. OT, while important as the endogenous ligand, might also not be the ideal ligand for therapeutic development, considering that it also activates the three to OTR closely related vasopressin receptors $\left(\mathrm{V}_{1 \mathrm{a}} \mathrm{R}, \mathrm{V}_{1 \mathrm{~b}} \mathrm{R}, \mathrm{V}_{2} \mathrm{R}\right.$, discussed in sections below) [103] and its short systemic half-life [104]. More systematic studies and OTR drug lead development is, in our opinion, necessary before moving towards clinical translation.

\section{In vitro studies}

OT has antiproliferative effects in several human breast cancer cell lines, including MDA-MB-231 [40, 94], MCF-7

Table 2 Effects of OT analogues on breast cancer cell proliferation in vitro.

\begin{tabular}{|c|c|c|c|c|}
\hline Cell lines & Ligands & Conditions & Effects & Reference \\
\hline HMEC, B-TEC & OT, $10^{-9}-10^{-6} \mathrm{M}$ & $\begin{array}{l}10 \% \text { FCS or serum free, medium } \\
\text { changed every } 48 \mathrm{~h}\end{array}$ & $\begin{array}{l}\text { Stimulation (proliferation } \\
\& \text { migration) }\end{array}$ & [91] \\
\hline MCF-7 & $\begin{array}{l}\text { OT, } 10^{-11}-10^{-9} \mathrm{M} \\
\text { VP, } 10^{-8} \mathrm{M} \\
\text { VP, } 10^{-11}-10^{-9} \mathrm{M}\end{array}$ & $2.5 \% \mathrm{FCS}$ & $\begin{array}{l}\text { Stimulation } \\
\text { Inhibition } \\
\text { Stimulation }\end{array}$ & [59] \\
\hline MCF-7 & OT, $10^{-7} \mathrm{M}$ & $\begin{array}{l}2 \% \text { FCS in medium with E } 2 \text { or CS- } \\
\text { FCS in phenol red-free medium }\end{array}$ & Inhibition & [92] \\
\hline MCF-7, SK-BR-3 & $\begin{array}{l}\text { VP, } 10^{-8} \mathrm{M} \\
\text { Desmopressin, } 10^{-8} \mathrm{M}\end{array}$ & $5 \%$ CS-FCS & $\begin{array}{l}\text { Stimulation } \\
\text { Inhibition }\end{array}$ & {$[93]^{\mathrm{a}}$} \\
\hline MDA-MB-231 & OT, $10^{-7} \mathrm{M}$ & $10 \% \mathrm{FCS}$ & Inhibition & [94] \\
\hline MDA-MB-231, MCF-7 & OT, $10^{-7} \mathrm{M}$ & $10 \%$ FCS for 5 days & $\begin{array}{l}\text { Proliferation inhibition, } \\
\text { differentiation stimulation }\end{array}$ & [40] \\
\hline MDA-MB-231 & $\begin{array}{l}\text { OT, } 10^{-9} \mathrm{M}, 10^{-8} \mathrm{M}, 10^{-7} \mathrm{M} \text { AT, } \\
10^{-8} \mathrm{M}, 5 \times 10^{-8} \mathrm{M}\end{array}$ & $\begin{array}{l}5 \% \text { FCS, medium changed every } \\
24 \mathrm{~h}\end{array}$ & Inhibition & \\
\hline \multirow[t]{2}{*}{ MCF-7, T47D } & OT, $10^{-7} \mathrm{M}, 10^{-8} \mathrm{M}$ & $\begin{array}{l}5 \% \mathrm{FCS}, \text { medium changed every } \\
24 \mathrm{~h}\end{array}$ & No effects & \\
\hline & & $\begin{array}{l}10 \% \text { FCS, E2, TAM, medium } \\
\text { changed every } 24 \mathrm{~h}\end{array}$ & Inhibition & \\
\hline $\begin{array}{l}\text { MDA-MB-231, MDA-MB- } \\
\text { 361, MDA-MB-468, MCF-7 }\end{array}$ & OT, $10^{-9} \mathrm{M}, 10^{-7} \mathrm{M}$ & $5 \% \mathrm{FCS}$ & No effects & {$[88]$} \\
\hline Hs578T & OT, unspecified concentration & Not available & $\begin{array}{l}\text { No significant short-term } \\
\text { effects }\end{array}$ & {$[90]$} \\
\hline MCF7, TS/A (mouse) & $\begin{array}{l}\text { LVT, } 10^{-8} \mathrm{M}, 10^{-7} \mathrm{M} 10^{-6} \mathrm{M} \\
\text { DOTA-LVT, } 10^{-8} \mathrm{M}, 10^{-7} \mathrm{M} 10 \\
{ }^{-6} \mathrm{M}\end{array}$ & $10 \%$ FCS & $\begin{array}{l}\text { Inhibition } \\
\text { No effects }\end{array}$ & {$[100]^{\mathrm{b}}$} \\
\hline $\begin{array}{l}\text { MDA-MB-231 TS/A } \\
\text { (mouse) }\end{array}$ & OT, $10^{-8} \mathrm{M}, 10^{-7} \mathrm{M}$ & $10 \%$ FCS & Inhibition & {$[68]$} \\
\hline $\begin{array}{l}\text { TS/A (mouse) D- } \\
\text { R3230AC (rat) }\end{array}$ & OT, AT, $10^{-8} \mathrm{M}$ & $10 \%$ FCS & Inhibition & [96] \\
\hline CMT-U27 (canine) & OT, Desmopressin, $10^{-6} \mathrm{M}$ & $10 \% \mathrm{FBS}$ & Inhibition & [153] \\
\hline
\end{tabular}

$H M E C$ human dermal microvascular endothelial cells, $B$-TEC tumour-associated endothelial cells purified from human breast carcinomas, $F C S$ (FBS) fetal calf (bovine) serum, CS-FCS charcoal-stripped FCS, E2 17ß-estrodial, TAM tamoxifen, AT atosiban, $O T$ oxytocin, VP vasopressin, only two amino acids different from OT at position 3 and 8 , functions via vasopressin receptors $\mathrm{V}_{1 \mathrm{a}} \mathrm{R}, \mathrm{V}_{1 \mathrm{~b}} \mathrm{R}$, and $\mathrm{V}_{2} \mathrm{R}$, also can activate OTR; Desmopressin 1-(3-mercaptopropionic acid)-8-D-arginine-vasopressin $\left(\mathrm{V}_{1 \mathrm{~b}} \mathrm{R} / \mathrm{V}_{2} \mathrm{R}\right.$ agonist), an analogue of $\mathrm{VP}$ with longer half-life and improved selectivity for $\mathrm{V}_{2} \mathrm{R}$; LVT, Lys ${ }^{8}$-vasotocin, DOTA-LVT 1,4,7,10-tetraazacyclododecane-N,N',N",N"'-tetraacetic acid (DOTA) Lys ${ }^{8}$ vasotocin.

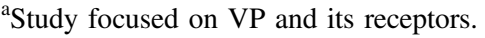

${ }^{\mathrm{b}}$ Study developed a radio-labelled ligand targeting OTR-expressing tumours, proliferation effects of the two ligands were also assessed. 
and T47D [40]. However, experimental conditions varied and some studies yielded contradictory data (Table 2). Multiple factors can affect OTR expression. For example, OTR expression in both $\mathrm{ER}^{+}$(MCF-7) and ER ${ }^{-}$(Hs578T) breast cancer cell lines can be increased by E2 treatment and decreased by progesterone treatment [87]. In the breast cancer Hs578T cell line, serum deprivation results in loss of OTR and serum restoration and addition of $1 \mu \mathrm{M}$ dexamethasone increases OTR mRNA levels by 9-fold [90]. The variability in OTR expression induced by hormones, serum and potentially other environmental changes may partially explain the contradictory results $[87,90]$. There are hormones (including E2 and OT) and growth factors present in serum, therefore, using charcoal-stripped FBS (CS-FBS) in the proliferation assay, which can reduce effects of the hormones and growth factors in FBS [105], could be a critical factor to consider in the in vitro study of the OT/ OTR system.

It is also worth noting that most of these studies used human breast cancer cell lines that are not derived from primary, untreated breast tumours, but from advanced-stage, often pre-treated, tumours, metastases, and pleural effusions. For example, SK-BR-3, MDA-MB-231, MCF-7, T47D and MDA-MB-468 are all derived from metastatic lesions' pleural effusions, and MDA-MB-361 are derived from a metastatic breast cancer site in the brain. Thus the results obtained are likely to be more indicative of rapidly progressive types of breast carcinoma and late-stage disease, rather than lower grade and earlier stages of breast cancers [106]. The outcomes of these in vitro studies highlight the need for a more systematic approach to study OTR as a target with highly reproducible experimental conditions and appropriate controls, including thorough monitoring and characterisation of the breast cancer cell lines used, such as their OTR expression levels and signalling pathways to provide a deeper and more controlled understanding of the mechanisms underlying these conflicting effects.

\section{Basic molecular biology of the OTR and its signalling pathways in breast cancer}

OTR comprises three extracellular loops (EL1-EL3), seven transmembrane $\alpha$-helices (7TM) and three intracellular loops (ICL1-ICL3) [107], with the N-terminus at the extracellular and the $\mathrm{C}$-terminus the intracellular side. The intracellular domains and loops of OTR couple to G protein $\alpha, \beta$ and $\gamma$ subunits, which are at the top of the signalling cascade. Ligands bind to OTR in an extracellularly accessible membrane binding pocket, which induces a conformational change leading to the recruitment of $G$ proteins.

Upon receptor activation (e.g., via OT), OTR can signal via multiple $\mathrm{G}$ protein-dependent and $\mathrm{G}$ protein-independent pathways that activate signalling cascades including a variety of second messenger systems, as well as members of the Ras and Rho families of small GTP-binding proteins. These pathways have multiple effects and understanding of the various signalling cascades is important, as it might provide clues on its role in breast cancer as well as potential targets for pharmacotherapy. The impact of OTR signalling via $G$ protein-dependent/-independent and downstream effector proteins is thus discussed in the following paragraphs, particularly in terms of molecular mechanisms influencing breast cancer cell proliferation and migration.

\section{G protein-dependent signalling of OTR}

OT and other OTR agonists promote the replacement of guanosine-5'-diphosphate (GDP) with guanosine-5'-triphosphate (GTP) to interact with the $\mathrm{G} \alpha$ subunit, subsequently causing the dissociation of $\mathrm{G} \alpha$ from $\mathrm{G} \beta \gamma$ subunits and ultimately affecting different downstream effectors or signalling events. OTR can engage in vitro with $\mathrm{G} \alpha_{\mathrm{q} / 11}, \mathrm{G} \alpha_{\mathrm{i} / \mathrm{o}}$ and $\mathrm{G} \alpha_{\mathrm{s}}$, which further signal through their second messengers $\mathrm{IP}_{3}$ (inositol 1,4,5-trisphosphate), DAG (diacylglycerol), $\mathrm{Ca}^{2+}$ or cAMP (cyclic adenosine monophosphate) to trigger a multitude of intracellular signalling events (Fig. 2) [108-111]. While OTR $\mathrm{G} \alpha_{\mathrm{q} / 11}$ and $\mathrm{G} \alpha_{\mathrm{i} / \mathrm{o}}$ recruitment and signaling is well established, OTR/G $\alpha_{\mathrm{s}}$ signaling remains questionable, with only low [84] or no significant $\mathrm{G} \alpha_{\mathrm{s}}$ recruitment [99] observed.

Activation of the $\mathrm{G} \alpha_{\mathrm{q} / 11}$ pathway might be a critical factor for proliferative effects of OT since it induces an increase of $\mathrm{IP}_{3}$ or intracellular calcium $\left(\left[\mathrm{Ca}^{2+}\right]_{\mathrm{i}}\right)$, which further promotes protein tyrosine phosphorylation-an early event of proliferative signalling triggered also by growth factors $[13,15]$. For example, the increase in $\left[\mathrm{Ca}^{2+}\right]_{i}$ plays a role in the stimulation of cell proliferation in smallcell lung cancer [12], trophoblast and choriocarcinoma [13], and Kaposi's sarcoma [15]. However, the effects of these OT-induced intracellular changes vary across different breast cancer cell lines, for example, leading to an increase of total inositol phosphates in MCF-7 cells resulting in proliferation [59], no change of $\left[\mathrm{Ca}^{2+}\right]_{i}$ in MDA-MB-231 cells with proliferation inhibition associated with cAMP signalling [94], no change of $\left[\mathrm{Ca}^{2+}\right]_{i}$ in T47D cells [112] with antiproliferative effects [40], and a time- and concentration-dependent increase in $\left[\mathrm{Ca}^{2+}\right]_{\mathrm{i}}$ in Hs578T cells with no significant effects on proliferation [90]. Mitogenic effects of OT on MCF-7 [59], HEMC and B-TEC cells [91] were also associated with $\mathrm{G} \alpha_{\mathrm{q} / 11}$ pathway activation resulting in $\mathrm{IP}_{3}$ or $\left[\mathrm{Ca}^{2+}\right]_{i}$ increase. $\mathrm{G} \beta \gamma$ subunits released by $\mathrm{OTR} / \mathrm{G} \alpha_{\mathrm{q} / 11}$ activation can lead to ERK1/2 activation in myometrial cells via a PLC-independent pathway, involving EGFR activation and calcium requirement [113]. This might help to explain some of the proliferation effects of OT 


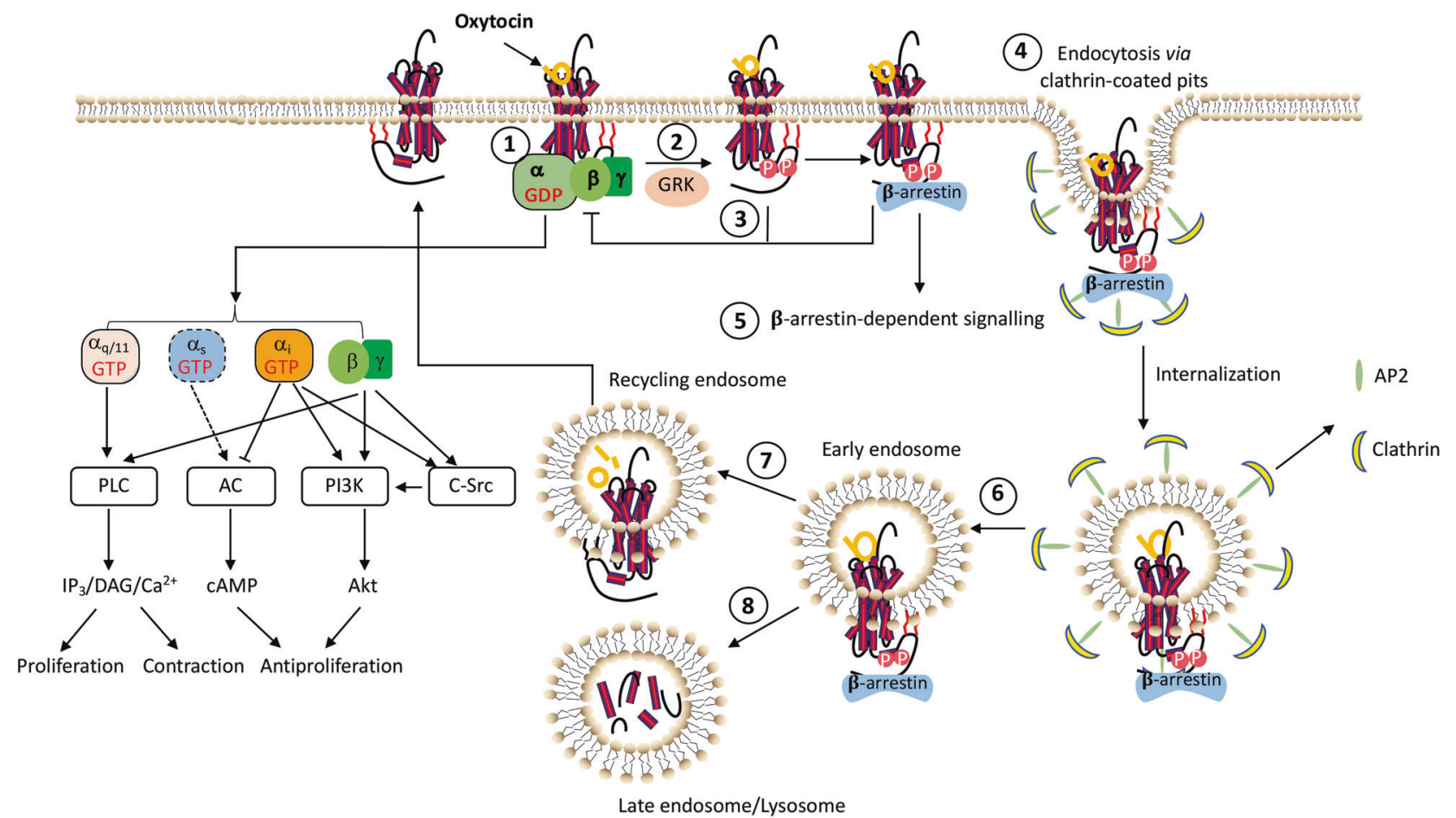

Fig. 2 Schematic pathway diagram of $G$ protein-dependent and $\boldsymbol{\beta}$-arrestin-dependent signalling via OTR. Upon agonist binding: (1) OTR signals via $G$ proteins - the classic signalling route for $G \alpha_{q / 11}$ is activation of phospholipase $\mathrm{C}$ (PLC) thereby triggering phosphoinositide hydrolysis, calcium mobilisation and protein kinase A (PKA) activation. $\mathrm{G} \alpha_{\mathrm{S}}$ activates adenylate cyclase (AC), which in turn increases cAMP production, leading to the activation of cAMPdependent PKA. The OTR/G $\alpha_{s}$ pathway (dashed lines) is not fully confirmed yet and requires further study. The classical signalling pathway for $\mathrm{G} \alpha_{\mathrm{i}}$ is inhibition of AC which leads to a decreased cAMP production and decreased PKA activity. (2) In addition, OTR can be phosphorylated at the C-terminus or at intracellular loops by GPCR

in breast cancer cell lines with changes in $\mathrm{IP}_{3}$ or $\left[\mathrm{Ca}^{2+}\right]_{\mathrm{i}}$ signalling.

Low amounts of $\mathrm{G} \alpha_{s}$ complexation with OTR was observed in rat myometrium [84], but such a $\mathrm{G} \alpha_{\mathrm{s}}$ interaction was not confirmed in a bioluminescence resonance energy transfer (BRET) study looking at $\mathrm{G}$ protein recruitment at the human OTR [99]. In the triple-negative MDA-MB-231 cell line, OT displayed antiproliferative effects associated with an increase in intracellular cAMP levels and activation of PKA, with no involvement of the $\mathrm{Ca}^{2+}$-phosphoinositide system, which might be linked to the $\mathrm{G} \alpha_{\mathrm{s}}$ pathway [94]. In Hs578T cells, OT promoted the synthesis of prostaglandins [90], which may indirectly involve the activation of $\mathrm{G \alpha}_{\mathrm{s}}$ coupled prostaglandin receptors [114]. At this stage, the $\mathrm{OTR} / \mathrm{G} \alpha_{\mathrm{s}}$ pathway remains questionable and requires further investigation.

OTR coupling to $\mathrm{G}_{\mathrm{i}}$ is especially crucial for cell growth inhibition since pertussis toxin (PTX) treatment, which inhibits $\mathrm{G} \alpha_{i}$ protein-receptor coupling, entirely abolished the inhibitory effects mediated by GFP-tagged OTR kinases (GRK). (3) Once phosphorylated, OTR loses its affinity for the $\mathrm{G}$ proteins and gains affinity for $\beta$-arrestins. $\beta$-arrestins bound to OTR prevent further coupling of $\mathrm{G}$ proteins, a process known as desensitisation. (4) $\beta$-arrestins, through their interaction with clathrin and adaptor protein 2 (AP-2), target phosphorylated OTRs for endocytosis via clathrin-coated pits by scaffolding proteins of the internalisation machinery. (5) OTR can also activate $\beta$-arrestin-dependent signalling pathways. (6) Internalised OTRs move into early endosomes, of which some are sorted into recycling endosomes, where the ligand is metabolised and the receptors are dephosphorylated and recycled back to the cell surface (7), while others are sorted to late endosomes/lysosomes for degradation (8).

stimulation. Meanwhile, inhibition of PLC with its inhibitor U73122 also abolished the inhibition of cell growth by OTR coupling to $\mathrm{G} \alpha_{\mathrm{i}}$, which is possibly a result of PLC activation by the $\beta \gamma$ complexes released by $\mathrm{G}_{\mathrm{i}}$ [115]. The $\mathrm{G} \alpha_{\mathrm{i}}$ pathway appears to also mediate breast cancer growth inhibitory effects of OT, with the involvement of the PI3K/Akt pathway [56, 97]. In MCF-7 cells, which express OTR and feature a PI3K activating mutation, a $30 \mathrm{~min}$ incubation with OT $(125-1,000 \mathrm{nM})$ reduced the abundance of PI3K signalling components, including a reduction of PI3K p85, PI3K p110, and pAktS $S^{473}$, and Akt phosphorylation downstream of OTR requires $\mathrm{G} \alpha_{\mathrm{i}}$ and a structural change in the receptor [116]. $G \alpha_{i}$ and $\beta \gamma$ complexes are also probably involved in mediating c-Src and PI3K activation [115] which play crucial roles in breast cancer.

More systematic studies, including a range of welldefined and breast cancer subtype-related cell lines, are required to determine the functional role of modulating OTR and its downstream signalling pathways during disease development and progression. 


\section{G protein-independent signalling of OTR}

OTR also mediates $\mathrm{G}$ protein-independent signalling, which is less studied than $\mathrm{G}$ protein-dependent signalling. OTR stimulation and subsequent phosphorylation by GPCR kinases (GRKs) relay the primary steps in the induction of $G$ protein-independent signalling by inducing the recruitment of $\beta$-arrestins. While $\beta$-arrestins desensitise $G$ proteinmediated GPCR signalling, they also elicit $G$ proteinindependent signalling cascades, promoting cellular responses such as cell migration and proliferation [117]. For OTR, $\beta$-arrestins act as essential multifunctional adaptors in receptor desensitisation and trafficking, and some OTinduced OTR signalling depends on $\beta$-arrestins, such as the MAPK pathway [118].

OTR can bind both $\beta$-arrestin-1 and -2, forming a stable OTR/ $\beta$-arrestin complex, which internalises into endosomes. Some early endosomes are sorted into recycling endosomes, where the ligand is metabolised and OTR dephosphorylated and recycled back to the plasma membrane, while others are sorted to late endosomes/lysosomes for degradation (Fig. 2) $[119,120]$. OTR with OT bound to it has a higher potency for $\beta$-arrestin-2 than for $\beta$-arrestin-1 (BRET measurements of OTR-mediated $\beta$-arrestin- 1 and $\beta$-arrestin-2 recruitment induced by OT stimulation: $\mathrm{EC}_{50}$ of $41.15 \pm 1.85 \mathrm{nM}$ for $\beta$-arrestin-2 and $229 \pm 23.15 \mathrm{nM}$ for $\beta$-arrestin-1, 2 min for $\beta$-arrestin-2 and 5 min for $\beta$-arrestin-1 to reach BRET signal maximum plateau level) [99]. While $\beta$-arrestin binding can physically obstruct $G$ protein coupling, there exist also additional mechanisms by which $\beta$-arrestins block of $\mathrm{G}$ protein signalling [121]. OTR internalisation and desensitisation are induced upon agonist exposure through the classical clathrin-coated pits via $\beta$-arrestins (Fig. 2) [120]. For example, OT-induced internalisation of OTR occurs rapidly in a time- and OT dosedependent manner (e.g., $100 \mathrm{nM}$ OT, half-time of surface receptor loss is $2.3 \mathrm{~min}$, reaching $\sim 75 \%$ cell surface receptor loss after $1 \mathrm{~h}$ ) [120]. OTR internalisation and desensitisation has been studied and exploited for breast tumour visualisation and targeted treatment strategy in OTR-positive cancers $[100,101]$. For example, radio-labelled OT analogues are efficiently taken up by OTR-expressing TS/A mammary carcinoma cells both in vitro and in vivo $[100,101]$, and a macromolecular conjugate of paclitaxel bearing OT as a targeting moiety was successfully delivered into OTR-positive breast cancer MCF-7 cells [122].

Receptor dimerization, compartmentalisation and trafficking, as well as receptor-transducer-effector stoichiometry and ligand residence and exposure times can each affect OTR coupling. Extrinsic factors, such as cell type or assay conditions, can also influence receptor signalling. Considering the complexity and heterogenicity of breast cancer and OTR signalling, it is critical to take the molecular characteristics of different breast cancer subtypes and cell types into consideration when studying OTRmediated pathways in breast cancer. In addition, it is important to acquire a more comprehensive understanding of the physiological and pathological consequences of both $\mathrm{G}$ protein-dependent and $\beta$-arrestin-dependent signalling (including $\beta$-arrestin-1 and -2 pathways), particularly when it comes to targeting OTR in breast cancer.

\section{Biased signalling}

OTR can promiscuously engage with multiple $G$ proteins and initiate various signalling pathways in different cell systems. OT can activate $\mathrm{G} \alpha_{\mathrm{q}}$, all members of the $\mathrm{G} \alpha_{\mathrm{i} / \mathrm{o}}$ families including $\mathrm{G \alpha}_{\mathrm{i} 1}, \mathrm{G} \alpha_{\mathrm{i} 2}, \mathrm{G} \alpha_{\mathrm{i} 3}, \mathrm{G} \alpha_{\mathrm{oA}}$, and $\mathrm{G} \alpha_{\mathrm{oB}}\left(\mathrm{EC}_{50}\right.$ of OT for activation of different OTR-G protein complexes in HEK293 cells by BRET: $\mathrm{G} \alpha_{\mathrm{q}}, 2.2 \mathrm{nM} ; \mathrm{G} \alpha_{\mathrm{i}}, 11.5 \mathrm{nM}$; $\mathrm{G} \alpha_{\mathrm{oA}}, 29.8 \mathrm{nM} ; \mathrm{G}_{\mathrm{i} 2}, 32.3 \mathrm{nM} ; \mathrm{G} \alpha_{\mathrm{i} 1}, 62.6 \mathrm{nM}$ and $\mathrm{G} \alpha_{\mathrm{oB}}$, $91.8 \mathrm{nM}$ ) [99], and maybe $\mathrm{G} \alpha_{\mathrm{s}}$ [84]. It is possible to identify ligands to direct signalling towards a selected $G$ proteindependent or $\mathrm{G}$ protein-independent downstream signalling pathway, a concept called 'biased signalling' [123, 124]. Biased signalling can be encoded through three general mechanisms including biased ligand, biased receptor, or biased system [124]. OTR can elicit specific signalling pathway transduction via biased ligands and via its localisation within caveolae.

The well-characterised OT analogues AT and DNalOVT [125] are biased ligands that block the $\mathrm{G} \alpha_{q / 11}$ pathway while activating the $\mathrm{G \alpha}_{\mathrm{i} 3}$ (AT) or $\mathrm{G} \alpha_{\mathrm{i} 1}$ (DNalOVT) pathways [99]; another example is carbetocin, a functional selective $\mathrm{G \alpha}_{\mathrm{q} / 11}$ agonist promoting OTR internalisation via a $\beta$-arrestin-independent manner [126]. Such biased ligands are valuable probes to dissect the complex OTR-dependent signalling pathways, particularly when it comes to OTR's involvement in (breast) cancer. For example, AT, which favours $G \alpha_{\mathrm{i} / \mathrm{o}}$ over $\mathrm{G} \alpha_{\mathrm{q} / 11}$ coupling [98], significantly inhibits rat and mouse breast tumour growth both in vitro and in vivo $[68,96]$. Indeed, OTR coupling to $\mathrm{G}_{\mathrm{i}}$ seems to be especially important in mediating the inhibition of cell growth [115], and independent activation of either $\mathrm{G} \alpha_{i 1}$ (by DNalOVT) or $\mathrm{G}_{\mathrm{i} 3}$ (by AT) can lead to growth inhibition in

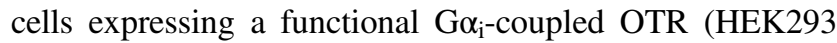
cells stably expressing the OTR-enhanced green fluorescent protein and DU145 human prostate cancer cells expressing endogenous OTR) [99]. These selected $\mathrm{G} \alpha_{i}$ pathway activation studies with AT and DNaIOVT are the first experimental evidence that activation of the OTR-G $\alpha_{i}$ pathway could be responsible for the observed tumour growth inhibition effects [98].

In addition to $G$ protein and $\beta$-arrestin, localisation of OTR in caveolae can also induce biased signalling. Caveolae are small pits of $50-60 \mathrm{~nm}$ in diameter on the 
plasma membrane, with peripheral membrane proteins called cavins coating the caveolar surface and caveolins embedded in the interior membrane layer as the main structural components [127]. OTR does not undergo internalisation through the clathrin-mediated route when it is located in the caveolae. It activates the MAP kinase in a Ras-dependent pathway leading to transient activation ( $<30 \mathrm{~min})$ and translocation of EGFR/ERK1/2 and stimulates cell proliferation, and this may be due to the increased affinity of OTR coupled to $G \alpha_{q / 11}$, because PTX pretreatment did not block the mitogenic effect. When OTR is outside the caveolin-enriched domains, its activation leads to sustained activation ( $>3 \mathrm{~h}$ ) of EGFR/ERK1/2 through a $\mathrm{G} \alpha_{\mathrm{i}^{-}}$, PLC-, c-Src- and PI3K-independent pathway, altering its regulatory effects on proliferation towards antiproliferative, by engaging the cell cycle inhibitor p21WAF1/CIP1 [114, 115].

Biased signalling could be a reason for observing different proliferation results (proliferative, antiproliferative and no effects) in response to OTR activation. Indeed, the findings discussed above point towards targeting specific OTR pathways for clinical application, indicating that the $\mathrm{G}_{\mathrm{i}}$ pathway in particular might play an important role in disease progression. Investigation of the specific OTR pathways with well-characterised biased ligands is thus encouraged to advance our understanding of OTR in breast cancer development and progression.

\section{Links between the OTR and the oestrogen receptor in breast cancer}

OTR also interacts with other proteins, some of which are highly relevant and dysregulated in breast cancer, such as the oestrogen receptors (ERs), which are present in approximately $75 \%$ of all breast cancer cases. ERs include two subtypes, ER $\alpha$ and ER $\beta$, encoded by ESR1 and ESR2, respectively, which can function at the membrane or within the nucleus [128]. ER $\alpha$ is the most studied subtype due to its clinical significance, while the clinical relevance of ER $\beta$ remains obscure [129]. The abbreviation ER thus refers mainly to ER $\alpha$ in the text below as well as in the literature. ER responds to oestrogen, which exists endogenously as three major forms in females, namely estrone (E1), estradiol (E2), and estriol (E3), another type of oestrogen, estetrol (E4), is specific to pregnancy. In breast cancer epithelial cells, the mitogenic action of E2 is mediated via ER $\alpha$ and $\operatorname{ER} \beta$ [130].

OTR expression is modulated by E2. Increased OTR mRNA expression is observed not only in normal mammary myoepithelium but also in human breast cancer cell lines MCF-7 (ER ${ }^{+}$) and Hs578T (ER $\left.{ }^{-}\right)$that were exposed to E2 $\left(10^{-7} \mathrm{M}\right.$ or $\left.10^{-6} \mathrm{M}, 24 \mathrm{~h}\right)$ [87]. In MCF-7 and T47D (ER $\left.{ }^{+}\right)$ cell lines, $30 \mathrm{~min}$ of $10 \mathrm{nM}$ E2 treatment yielded a 100 -fold increase in the OTR mRNA expression [37]. However, the correlation between OTR expression and $\mathrm{ER}^{+}$breast tumours is not consistent among studies [58, 68, 88]. The increased OTR levels with E2 dominance indicate that there is a potential for these tissues to be sensitive to OTRmediated effects, including inhibition of tumour growth [131]. For example, OT inhibits E2-induced growth of MCF-7 and T47D cells, and increases the antiproliferative effects of tamoxifen in these $\mathrm{ER}^{+}$cells [40]. Conversely, OT can also influence tumour growth indirectly, by affecting ER expression or function. Accordingly, OT treatment in MCF-7 cells downregulates ER and therefore the oestrogen-dependent mitogenic response [92]. Multi-drugresistant breast cancer cell lines also feature OTR overexpression [132]. Therefore patients with $\mathrm{ER}^{+}$breast tumours, which have intrinsic or acquired resistance for endocrine manipulation, are likely to benefit from an OTRtargeting therapeutic approach.

The correlation between OTR and ER and its significance remains to be clarified further with larger sample sizes; however, an OTR-targeting therapy might display synergistic effects with an ER-targeting therapy and could contribute to the battle against drug resistance of $\mathrm{ER}^{+}$breast cancer.

\section{Bottlenecks and strategies of targeting the OTR for breast cancer management}

As a GPCR, OTR is a highly druggable target, and targeting OTR in breast cancer could lead to improved treatment and diagnostic options of this heterogeneous disease. Nonetheless, there is still no OT analogues undergoing clinical trials for cancer treatments. Broader and more systematic studies are required to define the therapeutic potential of OTR in breast cancer. In the following section, we discuss current bottlenecks as well as potential drug development strategies.

\section{Bottlenecks for targeting OTR in breast cancer}

Vasopressin (VP) with its three receptors (VPRs), $\mathrm{V}_{1 \mathrm{a}} \mathrm{R}$, $\mathrm{V}_{1 \mathrm{~b}} \mathrm{R}$, and $\mathrm{V}_{2} \mathrm{R}$, are closely related to OT/OTR, constituting one of the most complex and important neuroendocrine systems in humans. Human VP is highly homologous to OT, with only two amino acids different at positions 3 and 8 (VP, CYFQNCPRG). Members of the OT/VP-receptor family are highly conserved sharing a high degree of sequence similarity, about 100 conserved amino acids among the 370-420 amino acids, especially in the extracellular loops and the transmembrane helices (Fig. 3) $[4,8,133]$. The homology of the binding sites of the OTR 


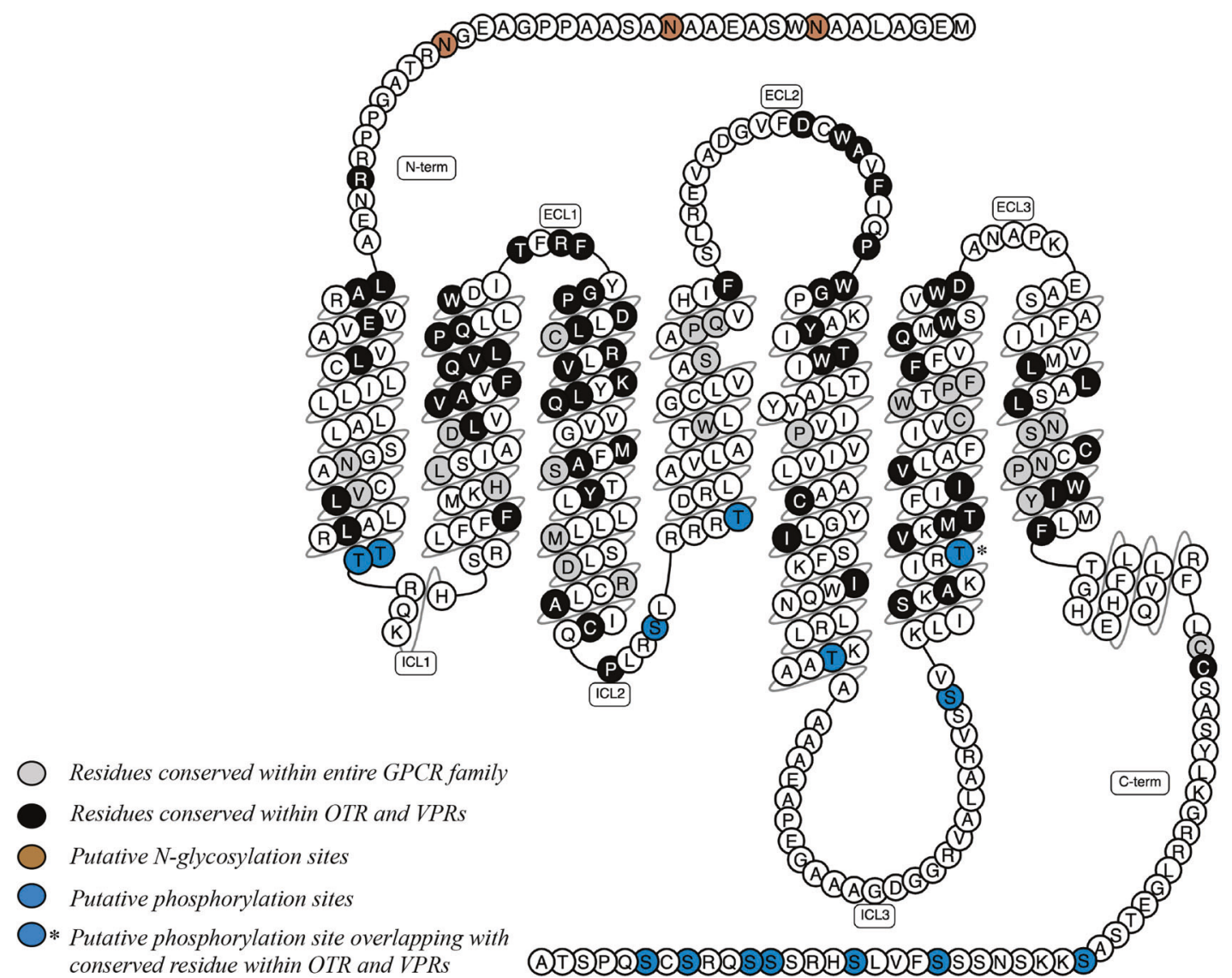

Fig. 3 The structure and sequence of human OTR, with amino acids presented as single-letter codes. Residues conserved within OTR and VPRs are coloured in black, residues conserved within the entire family of GPCRs are coloured in grey, putative N-glycosylation sites are coloured in brown, putative phosphorylation sites are

and VPRs is $\sim 80 \%$, thus leading to significant cross-talk $[103,134,135]$. OT can not only activate OTR, but also the VPRs, while VP can also activate OTR. Hence, if OT and OT analogues inhibit proliferation, it cannot be simply concluded that this occurs exclusively via OTR-since VPRs might also be present and play a role. OTR-selective ligands are thus critical to define the role of OTR in breast cancer [99, 103, 125, 136]. Receptor-selective ligands are also important for drug development, since unspecific offtarget effects can lead to undesired side effects (e.g., $V_{1 \mathrm{a}} \mathrm{R}$ regulates cardiovascular functions, $\mathrm{V}_{2} \mathrm{R}$ regulates kidney functions) $[137,138]$.

Another barrier for studying the OT/OTR system in breast cancer is the lack of OTR protein expression data in human tissues. Most OTR expression data in breast cancer tissues are on gene expression levels determined by PCR and in situ hybridizations [37, 40, 68, 139], and there are several more gene expression data sets being generated by a variety of high-throughput hybridization array- and sequencing-based techniques (e.g., RNA-seq and ChIP-seq), accessible through databases such as Gene Expression Omnibus (GEO) [140]. coloured in blue, and putative phosphorylation sites overlapping with conserved residue within OTR and VPRs are coloured in blue and marked with an asterisk. The receptor scheme was adapted from GPCRdb website [133], the conserved residues were adapted from [4], and the putative phosphorylation sites were adapted from [111].

However, gene expression levels are not always indicative of protein abundance. The high homology of the extracellular loops of the receptors is a major problem for OTR/VPR antibody selectivity, which, to date, is still unsatisfying for OTR protein detection. All of the OT/VP receptors have putative glycosylation sites at the N-terminus (Fig. 3) [141], which is another hurdle for OTR protein detection [142], since it induces a variation of OTR's molecular mass, rendering detection by western blotting ambiguous and often inconclusive [142]. This results in limited and reliable OTR protein expression data to date [78].

Even though biased signalling might explain some of the contradictory data on OT analogues in breast cancer growth, it is not always clear which specific pathway mediates a beneficial or adverse therapeutic response [123]. Identification of the relevant signalling pathways for breast cancer is however critical as this will form the basis for a more directed, if not a rational, ligand design towards novel treatment options.

Breast cancer, like many other cancers, is not just a single disease but a group of biologically and molecularly 
heterogeneous disease subtypes [143], each characterised by distinct morphology, biomarkers, behaviour and clinical implications. It is thus important to further explore the therapeutic potential of the OT/OTR system in breast cancer and expand these studies across a broader range of breast cancer subtypes. It also remains unclear how an acute or single dose of OT analogues compares versus a long-term continuous administration affects in terms of breast cancer growth. Therefore, elucidating the distribution of OTR under physiological and specific pathological conditions in human breast and their corresponding precise molecular signalling pathways should be a continuing research focus.

\section{Strategies for targeting OTR in breast cancer}

The demonstrated druggability of OTR and its involvement in breast cancer provides a driving force for drug development in this field. Many OT-like peptides have been developed with improved selectivity and more drug-like properties [125, 144]. Bioactive OT/VP-like peptides from natural sources form promising starting points for the identification of pharmaceutical lead compounds, a strategy that our laboratories have pursued now for many years [7]. It takes advantage of the evolutionary conservation of this signalling system across the animal kingdom and provides high hit-rates for the discovery of bioactive OT ligands with often unique and therapeutically relevant pharmacology $[8,136,145-147]$. These ligands play an important role in dissecting these cancer-related signalling pathways and, combined with state-of-the-art medicinal chemistry, also form exquisite starting points for drug development programs [103, 148-151].

Biased signalling is gaining prominence, which raises the possibility of directly screening for OTR-specific G proteindependent or independent pathway modulators. These ligands will play an important role in the dissection of OTR signalling pathways and function as well as in advancing our understanding of the pathway-specific role in breast cancer progression. One of the most commonly used techniques to study GPCR pathways signal transduction is BRET, which is currently the preferred technique to identify and characterise biased ligands for the OTR signalling system [99].

\section{Conclusions and future directions}

Accumulating evidence underpins the involvement of the OT/OTR signalling system in breast cancer development. This warrants further investigation, ideally in a systematic and well-controlled way using state-of-the-art techniques. The use of receptor-subtype selective, if not biased, ligands is critical to study the preventive and tumour reducing capabilities of the OT/OTR signalling system in breast cancer. A thorough understanding of OTR's signalling pathways in controlling breast cancer formation and progression is mandatory to understand the pathological process and to design an OTR-based therapeutic approach. From a drug development point of view, OTR represents a promising therapeutic target for breast cancer diagnosis and treatment that is worth pursuing.

Acknowledgements Funding supporting the studies are listed as follows: MM was supported by the European Research Council under the European Union's Horizon 2020 research and innovation program (714366) and by the Australian Research Council (DP190101667). MM, PFA and AM were supported by grants from Cancer Australia and Cancer Council Queensland (1146504). AM was supported by a grant from the National Breast Cancer Foundation Australia (IIRS18-159). CWG has been supported by the Austrian Science Fund (FWF) through projects I3243 and P32109. HL is supported by the Research Training Scholarship of The University of Queensland.

\section{Compliance with ethical standards}

Conflict of interest The authors declare that they have no conflict of interest.

Publisher's note Springer Nature remains neutral with regard to jurisdictional claims in published maps and institutional affiliations.

Open Access This article is licensed under a Creative Commons Attribution 4.0 International License, which permits use, sharing, adaptation, distribution and reproduction in any medium or format, as long as you give appropriate credit to the original author(s) and the source, provide a link to the Creative Commons license, and indicate if changes were made. The images or other third party material in this article are included in the article's Creative Commons license, unless indicated otherwise in a credit line to the material. If material is not included in the article's Creative Commons license and your intended use is not permitted by statutory regulation or exceeds the permitted use, you will need to obtain permission directly from the copyright holder. To view a copy of this license, visit http://creativecommons. org/licenses/by/4.0/.

\section{References}

1. Bray F, Ferlay J, Soerjomataram I, Siegel RL, Torre LA, Jemal A. Global cancer statistics 2018: GLOBOCAN estimates of incidence and mortality worldwide for 36 cancers in 185 countries. CA Cancer J Clin. 2018;68:394-424.

2. Miller KD, Siegel RL, Lin CC, Mariotto AB, Kramer JL, Rowland $\mathrm{JH}$, et al. Cancer treatment and survivorship statistics 2016. CA Cancer J Clin. 2016;66:271-89.

3. Siegel RL, Miller KD, Jemal A. Cancer statistic, 2020. CA Cancer J Clin. 2020;70:7-30.

4. Gimpl G, Fahrenholz F. The oxytocin receptor system: structure, function, and regulation. Physiol Rev. 2001;81:629-83.

5. Jurek B, Neumann ID. The oxytocin receptor: from intracellular signaling to behavior. Physiol Rev. 2018;98:1805-908.

6. Donaldson ZR, Young LJ. Oxytocin, vasopressin, and the neurogenetics of sociality. Science. 2008;322:900-4. 
7. Gruber CW, Koehbach J, Muttenthaler M. Exploring bioactive peptides from natural sources for oxytocin and vasopressin drug discovery. Future Med Chem. 2012;4:1791-8.

8. Koehbach J, Stockner T, Bergmayr C, Muttenthaler M, Gruber $\mathrm{CW}$. Insights into the molecular evolution of oxytocin receptor ligand binding. Biochem Soc Trans. 2013;41:197-204.

9. Lerman B, Harricharran T, Ogunwobi OO. Oxytocin and cancer: an emerging link. World J Clin Oncol. 2018;9:74-82.

10. Imanieh MH, Bagheri F, Alizadeh AM, Ashkani-Esfahani S. Oxytocin has therapeutic effects on cancer, a hypothesis. Eur J Pharmacol. 2014;741:112-23.

11. Strunecka A, Hynie S, Klenerova V. Role of oxytocin/oxytocin receptor system in regulation of cell growth and neoplastic processes. Folia Biol (Praha). 2009;55:159-65.

12. Pequeux C, Keegan BP, Hagelstein MT, Geenen V, Legros JJ, North WG. Oxytocin- and vasopressin-induced growth of human small-cell lung cancer is mediated by the mitogen-activated protein kinase pathway. Endocr Relat Cancer. 2004;11:871-85.

13. Cassoni P, Sapino A, Munaron L, Deaglio S, Chini B, Graziani A, et al. Activation of functional oxytocin receptors stimulates cell proliferation in human trophoblast and choriocarcinoma cell lines. Endocrinology. 2001;142:1130-6.

14. Petersson M, Lagumdzija A, Stark A, Bucht E. Oxytocin stimulates proliferation of human osteoblast-like cells. Peptides. 2002;23:1121-6.

15. Cassoni P, Sapino A, Deaglio S, Bussolati B, Volante M, Munaron L, et al. Oxytocin is a growth factor for Kaposi's sarcoma cells: evidence of endocrine-immunological cross-talk. Cancer Res. 2002;62:2406-13.

16. Cassoni P, Sapino A, Stella A, Fortunati N, Bussolati G. Presence and significance of oxytocin receptors in human neuroblastomas and glial tumors. Int J Cancer. 1998;77:695-700.

17. Cassoni P, Fulcheri E, Carcangiu ML, Stella A, Deaglio S, Bussolati G. Oxytocin receptors in human adenocarcinomas of the endometrium: presence and biological significance. J Pathol. 2000;190:470-7.

18. Busnelli M, Rimoldi V, Vigano P, Persani L, Di Blasio AM, Chini B. Oxytocin-induced cell growth proliferation in human myometrial cells and leiomyomas. Fertil Steril. 2010;94: 1869-74.

19. Morita T, Shibata K, Kikkawa F, Kajiyama H, Ino K, Mizutani S. Oxytocin inhibits the progression of human ovarian carcinoma cells in vitro and in vivo. Int J Cancer. 2004;109:525-32.

20. Xu H, Fu S, Chen Q, Gu M, Zhou J, Liu C, et al. The function of oxytocin: a potential biomarker for prostate cancer diagnosis and promoter of prostate cancer. Oncotarget. 2017;8:31215-26.

21. Whittington K, Connors B, King K, Assinder S, Hogarth K, Nicholson $\mathrm{H}$. The effect of oxytocin on cell proliferation in the human prostate is modulated by gonadal steroids: implications for benign prostatic hyperplasia and carcinoma of the prostate. Prostate. 2007;67:1132-42.

22. Petersson M. Opposite effects of oxytocin on proliferation of osteosarcoma cell lines. Regulatory Pept. 2008;150:50-4.

23. Newcomb PA, Storer BE, Longnecker MP, Mittendorf R, Greenberg ER, Clapp RW, et al. Lactation and a reduced risk of premenopausal breast cancer. N Engl J Med. 1994;330:81-7.

24. Collaborative Group on Hormonal Factors in Breast C. Breast cancer and breastfeeding: collaborative reanalysis of individual data from 47 epidemiological studies in 30 countries, including 50302 women with breast cancer and 96973 women without the disease. Lancet. 2002;360:187-95.

25. Li T, Wang P, Wang SC, Wang YF. Approaches mediating oxytocin regulation of the immune system. Front Immunol. 2016;7:693.

26. Wang P, Yang HP, Tian S, Wang L, Wang SC, Zhang F, et al. Oxytocin-secreting system: a major part of the neuroendocrine center regulating immunologic activity. J Neuroimmunol. 2015;289:152-61.

27. Macias H, Hinck L. Mammary gland development. Wiley Interdiscip Rev Dev Biol. 2012;1:533-57.

28. Desprez PY, Lin CQ, Thomasset N, Sympson CJ, Bissell MJ, Campisi J. A novel pathway for mammary epithelial cell invasion induced by the helix-loop-helix protein Id-1. Mol Cell Biol. 1998;18:4577-88.

29. Brisken C, O'Malley B. Hormone action in the mammary gland. Cold Spring Harb Perspect Biol. 2010;2:a003178.

30. Berryhill GE, Trott JF, Hovey RC. Mammary gland development-It's not just about estrogen. J Dairy Sci. 2016;99:875-83.

31. Neville MC, McFadden TB, Forsyth I. Hormonal regulation of mammary differentiation and milk secretion. J Mammary Gland Biol Neoplasia. 2002;7:49-66.

32. Hassiotou F, Geddes D. Anatomy of the human mammary gland: current status of knowledge. Clin Anat. 2013;26:29-48.

33. Benson GK, Folley SJ. The effect of oxytocin on mammary gland involution in the rat. J Endocrinol. 1957;16:189-201.

34. ÔTa K, Yokoyama A, Shinde Y. Effects of administration of oxytocin and prolactin on nucleic acids and phosphoprotein contents of mammary glands in lactating rats. Nature. 1962;195:77.

35. Yokoyama A, Ota K. Effect of oxytocin replacement on lactation in rats bearing hypothalamic lesions. Endocrinologia Japonica. 1959;6:268-76.

36. Mccann SM, Mack R, Gale C. The possible role of oxytocin in stimulating the release of prolactin. Endocrinology. 1959;64: 870-89.

37. Cassoni P, Marrocco T, Sapino A, Allia E, Bussolati G. Oxytocin synthesis within the normal and neoplastic breast: first evidence of a local peptide source. Int J Oncol. 2006;28:1263-8.

38. Sapino A, Macri L, Tonda L, Bussolati G. Oxytocin enhances myoepithelial cell differentiation and proliferation in the mouse mammary gland. Endocrinology. 1993;133:838-42.

39. Wagner KU, Young WS 3rd, Liu X, Ginns EI, Li M, Furth PA, et al. Oxytocin and milk removal are required for post-partum mammary-gland development. Genes Funct. 1997;1:233-44.

40. Cassoni P, Sapino A, Negro F, Bussolati G. Oxytocin inhibits proliferation of human breast cancer cell lines. Virchows Arch. 1994;425:467-72.

41. Murrell TG. The potential for oxytocin (OT) to prevent breast cancer: a hypothesis. Breast Cancer Res Treat. 1995;35:225-9.

42. Mustacchi P. Ramazzini and Rigoni-Stern on parity and breast cancer. Clinical impression and statistical corroboration. Arch Intern Med. 1961;108:639-42.

43. Le MG, Bachelot A, Hill C. Characteristics of reproductive life and risk of breast cancer in a case-control study of young nulliparous women. J Clin Epidemiol. 1989;42:1227-33.

44. Sugawara Y, Kakizaki M, Nagai M, Tomata Y, Hoshi R, Watanabe I, et al. Lactation pattern and the risk for hormonerelated female cancer in Japan: the Ohsaki Cohort Study. Eur J Cancer Prev. 2013;22:187-92.

45. Purwanto H, Sadjimin T, Dwiprahasto I. Lactation and the risk of breast cancer. Gan Kagaku Ryoho.2000;27(Suppl 2):474-81.

46. De Silva M, Senarath U, Gunatilake M, Lokuhetty D. Prolonged breastfeeding reduces risk of breast cancer in Sri Lankan women: a case-control study. Cancer Epidemiol. 2010;34:267-73.

47. Robinson VC. Support for the hypothesis that sexual breast stimulation is an ancestral practice and a key to understanding women's health. Med Hypotheses. 2015;85:976-85.

48. Carmichael MS, Humbert R, Dixen J, Palmisano G, Greenleaf W, Davidson JM. Plasma oxytocin increases in the human sexual response. J Clin Endocrinol Metab. 1987;64:27-31.

49. Graf C, Wessely N. Physical activity in the prevention and therapy of breast cancer. Breast Care. 2010;5:389-94. 
50. Patel AV, Callel EE, Bernstein L, Wu AH, Thun MJ. Recreational physical activity and risk of postmenopausal breast cancer in a large cohort of US women. Cancer Causes Control. 2003;14:519-29.

51. Bernstein L, Henderson BE, Hanisch R, Sullivan-Halley J, Ross RK. Physical exercise and reduced risk of breast cancer in young women. J Natl Cancer Inst. 1994;86:1403-8.

52. Landgraf R, Hacker R, Buhl H. Plasma vasopressin and oxytocin in response to exercise and during a day-night cycle in man. Endokrinologie. 1982;79:281-91.

53. Jong TR, Menon R, Bludau A, Grund T, Biermeier V, Klampfl $\mathrm{SM}$, et al. Salivary oxytocin concentrations in response to running, sexual self-stimulation, breastfeeding and the TSST: The Regensburg Oxytocin Challenge (ROC) study. Psychoneuroendocrinology. 2015;62:381-8.

54. Friedenreich CM. Physical activity and breast cancer: review of the epidemiologic evidence and biologic mechanisms. Recent Results Cancer Res. 2011;188:125-39.

55. Knols R, Aaronson NK, Uebelhart D, Fransen J, Aufdemkampe G. Physical exercise in cancer patients during and after medical treatment: a systematic review of randomized and controlled clinical trials. J Clin Oncol. 2005;23:3830-42.

56. Alizadeh AM, Heydari Z, Rahimi M, Bazgir B, Shirvani H, Alipour S, et al. Oxytocin mediates the beneficial effects of the exercise training on breast cancer. Exp Physiol. 2018;103:222-35.

57. Carrera-Gonzalez MP, Ramirez-Exposito MJ, de Saavedra JM, Sanchez-Agesta R, Mayas MD, Martinez-Martos JM. Hypothalamus-pituitary-thyroid axis disruption in rats with breast cancer is related to an altered endogenous oxytocin/insulin-regulated aminopeptidase (IRAP) system. Tumour Biol. 2011;32:543-9.

58. Ariana M, Pornour M, Mehr SS, Vaseghi H, Ganji SM, Alivand MR, et al. Preventive effects of oxytocin and oxytocin receptor in breast cancer pathogenesis. Per Med. 2019;16:25-34.

59. Taylor AH, Ang VT, Jenkins JS, Silverlight JJ, Coombes RC, Luqmani YA. Interaction of vasopressin and oxytocin with human breast carcinoma cells. Cancer Res. 1990;50:7882-6.

60. Martinez JM, Prieto I, Ramirez MJ, Cueva C, Alba F, Ramirez M. Aminopeptidase activities in breast cancer tissue. Clin Chem. 1999;45:1797-802.

61. Prevost M, Zelkowitz P, Tulandi T, Hayton B, Feeley N, Carter $\mathrm{CS}$, et al. Oxytocin in pregnancy and the postpartum: relations to labor and its management. Front Public Health. 2014;2:1.

62. Uvnas-Moberg K, Widstrom AM, Werner S, Matthiesen AS, Winberg J. Oxytocin and prolactin levels in breast-feeding women. Correlation with milk yield and duration of breastfeeding. Acta Obstet Gynecol Scand. 1990;69:301-6.

63. Iseri SO, Sener G, Saglam B, Gedik N, Ercan F, Yegen BC. Oxytocin protects against sepsis-induced multiple organ damage: role of neutrophils. J Surg Res. 2005;126:73-81.

64. Biyikli NK, Tugtepe H, Sener G, Velioglu-Ogunc A, Cetinel S, Midillioglu S, et al. Oxytocin alleviates oxidative renal injury in pyelonephritic rats via a neutrophil-dependent mechanism. Peptides. 2006;27:2249-57.

65. Szeto A, Nation DA, Mendez AJ, Dominguez-Bendala J, Brooks LG, Schneiderman N, et al. Oxytocin attenuates NADPHdependent superoxide activity and IL-6 secretion in macrophages and vascular cells. Am J Physiol Endocrinol Metab. 2008;295: E1495-501.

66. Nation DA, Szeto A, Mendez AJ, Brooks LG, Zaias J, Herderick $\mathrm{EE}$, et al. Oxytocin attenuates atherosclerosis and adipose tissue inflammation in socially isolated ApoE-/- mice. Psychosom Med. 2010;72:376-82.

67. Szeto A, Rossetti MA, Mendez AJ, Noller CM, Herderick EE, Gonzales JA, et al. Oxytocin administration attenuates atherosclerosis and inflammation in Watanabe Heritable Hyperlipidemic rabbits. Psychoneuroendocrinology. 2013;38:685-93.

68. Sapino A, Cassoni P, Stella A, Bussolati G. Oxytocin receptor within the breast: biological function and distribution. Anticancer Res. 1998;18:2181-6.

69. Li D, Ji Y, Zhao C, Yao Y, Yang A, Jin H. et al. OXTR overexpression leads to abnormal mammary gland development in mice. J Endocrinol. 2018;239:121-36.

70. Gimpl G. Oxytocin receptor ligands: a survey of the patent literature. Expert Opin Therapeutic Pat. 2008;18:1239-51.

71. PDQ Screening and Prevention Editorial Board. Breast Cancer Screening $\left(\mathrm{PDQ}^{\circledast}\right)$ : Patient Version. 2015 Nov 6. In: PDQ Cancer Information Summaries. Bethesda (MD): National Cancer Institute (US); 2002-. 2015; https://www.ncbi.nlm.nih.gov/ books/NBK65715.2/.

72. Takayanagi Y, Yoshida M, Bielsky IF, Ross HE, Kawamata M, Onaka T, et al. Pervasive social deficits, but normal parturition, in oxytocin receptor-deficient mice. Proc Natl Acad Sci USA. 2005;102:16096-16101.

73. Nishimori K, Young LJ, Guo Q, Wang Z, Insel TR, Matzuk MM. Oxytocin is required for nursing but is not essential for parturition or reproductive behavior. Proc Natl Acad Sci USA. 1996;93:11699-11704.

74. Breton C, Di Scala-Guenot D, Zingg HH. Oxytocin receptor gene expression in rat mammary gland: structural characterization and regulation. J Mol Endocrinol. 2001;27:175-89.

75. Zingg HH, Laporte SA. The oxytocin receptor. Trends Endocrinol Metab. 2003;14:222-7.

76. Ku C-Y, Qian A, Wen Y, Anwer K, Sanborn BM. Oxytocin stimulates myometrial guanosine triphosphatase and phospholipase-C activities via coupling to $\mathrm{G}$ alpha q/11. Endocrinology. 1995;136:1509-15.

77. Nakano H, Furuya K, Yamagishi S. Synergistic effects of ATP on oxytocin-induced intracellular $\mathrm{Ca} 2+$ response in mouse mammary myoepithelial cells. Pflug Arch. 2001;442:57-63.

78. Viero C, Shibuya I, Kitamura N, Verkhratsky A, Fujihara H, Katoh A, et al. REVIEW: Oxytocin: Crossing the bridge between basic science and pharmacotherapy. CNS Neurosci Ther. 2010;16:e138-56.

79. Sanborn BM, Ku CY, Shlykov S, Babich L. Molecular signaling through G-protein-coupled receptors and the control of intracellular calcium in myometrium. J Soc Gynecol Investig. 2005;12:479-87.

80. Svennersten-Sjaunja K, Olsson K. Endocrinology of milk production. Domest Anim Endocrinol. 2005;29:241-58.

81. Vrachnis N, Malamas FM, Sifakis S, Deligeoroglou E, Iliodromiti $Z$. The oxytocin-oxytocin receptor system and its antagonists as tocolytic agents. Int J Endocrinol. 2011;2011:350546.

82. Dhondt G, Houvenaghel A, Peeters G, Jochle W. Effect of prostaglandins F2alpha and E2 on milk ejection, blood pressure and blood flow through the mammary artery in the cow. Prostaglandins. 1977;13:1185-99.

83. Tahara M, Morishige K, Sawada K, Ikebuchi Y, Kawagishi R, Tasaka K, et al. RhoA/Rho-kinase cascade is involved in oxytocin-induced rat uterine contraction. Endocrinology. 2002;143:920-9.

84. Strakova Z, Soloff MS. Coupling of oxytocin receptor to G proteins in rat myometrium during labor: Gi receptor interaction. Am J Physiol. 1997;272:E870-6.

85. Zhou XB, Lutz S, Steffens F, Korth M, Wieland T. Oxytocin receptors differentially signal via $\mathrm{Gq}$ and $\mathrm{Gi}$ proteins in pregnant and nonpregnant rat uterine myocytes: implications for myometrial contractility. Mol Endocrinol. 2007;21:740-52.

86. Wang YF, Hatton GI. Dominant role of betagamma subunits of G-proteins in oxytocin-evoked burst firing. J Neurosci. 2007;27:1902-12. 
87. Amico JA, Rauk PN, Cai HM. Estradiol and progesterone regulate oxytocin receptor binding and expression in human breast cancer cell lines. Endocrine. 2002;18:79-84.

88. Ito Y, Kobayashi T, Kimura T, Matsuura N, Wakasugi E, Takeda $\mathrm{T}$, et al. Investigation of the oxytocin receptor expression in human breast cancer tissue using newly established monoclonal antibodies. Endocrinology. 1996;137:773-9.

89. Bussolati G, Cassoni P, Ghisolfi G, Negro F, Sapino A. Immunolocalization and gene expression of oxytocin receptors in carcinomas and non-neoplastic tissues of the breast. Am J Pathol. 1996;148:1895-903.

90. Copland JA, Jeng YJ, Strakova Z, Ives KL, Hellmich MR, Soloff MS. Demonstration of functional oxytocin receptors in human breast Hs578T cells and their up-regulation through a protein kinase C-dependent pathway. Endocrinology. 1999;140:2258-67.

91. Cassoni P, Marrocco T, Bussolati B, Allia E, Munaron L, Sapino $\mathrm{A}$, et al. Oxytocin induces proliferation and migration in immortalized human dermal microvascular endothelial cells and human breast tumor-derived endothelial cells. Mol Cancer Res. 2006;4:351-9.

92. Cassoni P, Catalano MG, Sapino A, Marrocco T, Fazzari A, Bussolati $\mathrm{G}$, et al. Oxytocin modulates estrogen receptor alpha expression and function in MCF7 human breast cancer cells. Int J Oncol. 2002;21:375-8.

93. Keegan BP, Akerman BL, Pequeux C, North WG. Provasopressin expression by breast cancer cells: implications for growth and novel treatment strategies. Breast Cancer Res Treat. 2006;95:265-77.

94. Cassoni P, Sapino A, Fortunati N, Munaron L, Chini B, Bussolati G. Oxytocin inhibits the proliferation of MDA-MB231 human breast-cancer cells via cyclic adenosine monophosphate and protein kinase A. Int J Cancer. 1997;72:340-4.

95. Benavente MA, Bianchi CP, Aba MA. Expression of oxytocin receptors in canine mammary tumours. J Comp Pathol. 2019;170:26-33.

96. Cassoni P, Sapino A, Papotti M, Bussolati G. Oxytocin and oxytocin-analogue F314 inhibit cell proliferation and tumor growth of rat and mouse mammary carcinomas. Int $\mathrm{J}$ Cancer. 1996;66:817-20.

97. Khori V, Alizadeh AM, Khalighfard S, Heidarian Y, Khodayari H. Oxytocin effects on the inhibition of the NF-kappaB/miR195 pathway in mice breast cancer. Peptides. 2018;107:54-60.

98. Reversi A, Rimoldi V, Marrocco T, Cassoni P, Bussolati G, Parenti $\mathrm{M}$, et al. The oxytocin receptor antagonist atosiban inhibits cell growth via a "biased agonist" mechanism. J Biol Chem. 2005;280:16311-8.

99. Busnelli M, Sauliere A, Manning M, Bouvier M, Gales C, Chini B. Functional selective oxytocin-derived agonists discriminate between individual $\mathrm{G}$ protein family subtypes. J Biol Chem. 2012;287:3617-29.

100. Bussolati G, Chinol M, Chini B, Nacca A, Cassoni P, Paganelli G. 111In-labeled 1,4,7,10-tetraazacyclododecane-N,N',N",N"'-tetraacetic acid-lys(8)-vasotocin: a new powerful radioligand for oxytocin receptor-expressing tumors. Cancer Res. 2001;61:4393-7.

101. Chini B, Chinol M, Cassoni P, Papi S, Reversi A, Areces L, et al. Improved radiotracing of oxytocin receptor-expressing tumours using the new [111In]-DOTA-Lys8-deamino-vasotocin analogue. Br J Cancer. 2003;89:930-6.

102. Takeda S, Kuwabara Y, Mizuno M. Metabolic clearance rate of oxytocin in human subjects. Nihon Naibunpi Gakkai Zasshi. 1989;65:182-9.

103. Muttenthaler M, Andersson A, Vetter I, Menon R, Busnelli M, Ragnarsson L. et al. Subtle modifications to oxytocin produce ligands that retain potency and improved selectivity across species. Sci Signal. 2017;10:eaan3398.
104. Gazis D. Plasma half-lives of vasopressin and oxytocin analogs after iv injection in rats. Proc Soc Exp Biol Med. 1978;158:663-5.

105. Dembinski TC, Leung CK, Shiu RP. Evidence for a novel pituitary factor that potentiates the mitogenic effect of estrogen in human breast cancer cells. Cancer Res. 1985;45:3083-9.

106. Vargo-Gogola T, Rosen JM. Modelling breast cancer: one size does not fit all. Nat Rev Cancer. 2007;7:659-72.

107. Katritch V, Cherezov V, Stevens RC. Diversity and modularity of $\mathrm{G}$ protein-coupled receptor structures. Trends Pharm Sci. 2012;33:17-27.

108. Neves SR, Ram PT, Iyengar R. G protein pathways. Science. 2002;296:1636-9.

109. Dorsam RT, Gutkind JS. G-protein-coupled receptors and cancer. Nat Rev Cancer. 2007;7:79-94.

110. Pierce KL, Premont RT, Lefkowitz RJ. Seven-transmembrane receptors. Nat Rev Mol Cell Biol. 2002;3:639-50.

111. Plested CP, Bernal AL. Desensitisation of the oxytocin receptor and other G-protein coupled receptors in the human myometrium. Exp Physiol. 2001;86:303-12.

112. Fay MJ, Du J, Longo KA, North WG. Oxytocin does not induce a rise in intracellular free calcium in human breast cancer cells. Res Commun Mol Pathol Pharmacol. 1999;103:115-28.

113. Zhong M, Yang M, Sanborn BM. Extracellular signal-regulated kinase $1 / 2$ activation by myometrial oxytocin receptor involves Galpha(q)Gbetagamma and epidermal growth factor receptor tyrosine kinase activation. Endocrinology. 2003;144:2947-56.

114. Guzzi F, Zanchetta D, Cassoni P, Guzzi V, Francolini M, Parenti $\mathrm{M}$, et al. Localization of the human oxytocin receptor in caveolin-1 enriched domains turns the receptor-mediated inhibition of cell growth into a proliferative response. Oncogene. 2002;21:1658-67.

115. Rimoldi V, Reversi A, Taverna E, Rosa P, Francolini M, Cassoni $\mathrm{P}$, et al. Oxytocin receptor elicits different EGFR/MAPK activation patterns depending on its localization in caveolin-1 enriched domains. Oncogene. 2003;22:6054-60.

116. Klein BY, Tamir H, Welch MG. PI3K/Akt responses to oxytocin stimulation in Caco2BB gut cells. $\mathrm{J}$ Cell Biochem. 2011;112:3216-26.

117. Shukla AK, Xiao K, Lefkowitz RJ. Emerging paradigms of betaarrestin-dependent seven transmembrane receptor signaling. Trends Biochem Sci. 2011;36:457-69.

118. Grotegut CA, Feng L, Mao L, Heine RP, Murtha AP, Rockman HA. beta-Arrestin mediates oxytocin receptor signaling, which regulates uterine contractility and cellular migration. Am J Physiol Endocrinol Metab. 2011;300:E468-77.

119. Conti F, Sertic S, Reversi A, Chini B. Intracellular trafficking of the human oxytocin receptor: evidence of receptor recycling via a Rab4/Rab5 "short cycle". Am J Physiol Endocrinol Metab. 2009;296:E532-42.

120. Smith MP, Ayad VJ, Mundell SJ, McArdle CA, Kelly E, Lopez Bernal A. Internalization and desensitization of the oxytocin receptor is inhibited by Dynamin and clathrin mutants in human embryonic kidney 293 cells. Mol Endocrinol. 2006;20:379-88.

121. Jean-Charles PY, Kaur S, Shenoy SKG. Protein-coupled receptor signaling through beta-arrestin-dependent mechanisms. J Cardiovasc Pharmacol. 2017;70:142-58.

122. Cavallaro G, Maniscalco L, Campisi M, Schillaci D, Giammona G. Synthesis, characterization and in vitro cytotoxicity studies of a macromolecular conjugate of paclitaxel bearing oxytocin as targeting moiety. Eur J Pharm Biopharm. 2007;66:182-92.

123. Seyedabadi M, Ghahremani MH, Albert PR. Biased signaling of G protein coupled receptors (GPCRs): molecular determinants of GPCR/transducer selectivity and therapeutic potential. Pharm Ther. 2019;200:148-78. 
124. Smith JS, Lefkowitz RJ, Rajagopal S. Biased signalling: from simple switches to allosteric microprocessors. Nat Rev Drug Discov. 2018;17:243-60.

125. Manning M, Stoev S, Chini B, Durroux T, Mouillac B, Guillon G. Peptide and non-peptide agonists and antagonists for the vasopressin and oxytocin V1a, V1b, V2 and OT receptors: research tools and potential therapeutic agents. Prog Brain Res. 2008;170:473-512.

126. Passoni I, Leonzino M, Gigliucci V, Chini B, Busnelli M. Carbetocin is a functional selective $\mathrm{Gq}$ agonist that does not promote oxytocin receptor recycling after inducing beta-arrestinindependent internalisation. J Neuroendocrinol. 2016;28.

127. Kovtun O, Tillu VA, Ariotti N, Parton RG, Collins BM. Cavin family proteins and the assembly of caveolae. J Cell Sci. 2015;128:1269-78.

128. Tang ZR, Zhang R, Lian ZX, Deng SL, Yu K. Estrogen-receptor expression and function in female reproductive disease. Cells. 2019;8:1123.

129. Yip $\mathrm{CH}$, Rhodes A. Estrogen and progesterone receptors in breast cancer. Future Oncol. 2014;10:2293-301.

130. Renoir JM, Marsaud V, Lazennec G. Estrogen receptor signaling as a target for novel breast cancer therapeutics. Biochem Pharmacol. 2013;85:449-65.

131. Nissenson R, Fluoret G, Hechter O. Opposing effects of estradiol and progesterone on oxytocin receptors in rabbit uterus. Proc Natl Acad Sci USA. 1978;75:2044-8.

132. Turton NJ, Judah DJ, Riley J, Davies R, Lipson D, Styles JA, et al. Gene expression and amplification in breast carcinoma cells with intrinsic and acquired doxorubicin resistance. Oncogene. 2001;20:1300-6.

133. Pandy-Szekeres G, Munk C, Tsonkov TM, Mordalski S, Harpsoe K, Hauser AS, et al. GPCRdb in 2018: adding GPCR structure models and ligands. Nucleic Acids Res. 2018;46: D440-6.

134. Chini B, Mouillac B, Balestre MN, Trumpp-Kallmeyer S, Hoflack J, Hibert M, et al. Two aromatic residues regulate the response of the human oxytocin receptor to the partial agonist arginine vasopressin. FEBS Lett. 1996;397:201-6.

135. Kimura T, Makino Y, Saji F, Takemura M, Inoue T, Kikuchi T, et al. Molecular characterization of a cloned human oxytocin receptor. Eur J Endocrinol. 1994;131:385-90.

136. Koehbach J, O’Brien M, Muttenthaler M, Miazzo M, Akcan M, Elliott AG, et al. Oxytocic plant cyclotides as templates for peptide $\mathrm{G}$ protein-coupled receptor ligand design. Proc Natl Acad Sci USA. 2013;110:21183-8.

137. Aoyagi T, Koshimizu TA, Tanoue A. Vasopressin regulation of blood pressure and volume: findings from V1a receptor-deficient mice. Kidney Int. 2009;76:1035-9.

138. Bankir L, Bichet DG, Morgenthaler NG. Vasopressin: physiology, assessment and osmosensation. J Intern Med. 2017;282: 284-97.

139. Cassoni P, Marrocco T, Deaglio S, Sapino A, Bussolati G. Biological relevance of oxytocin and oxytocin receptors in cancer cells and primary tumors. Ann Oncol. 2001;12(Suppl 2): S37-9.

140. Edgar R, Domrachev M, Lash AE. Gene Expression Omnibus: NCBI gene expression and hybridization array data repository. Nucleic Acids Res. 2002;30:207-10.

141. Wheatley M, Howl J, Yarwood NJ, Hawtin SR, Davies AR, Matthews G, et al. Structure and function of neurohypophysial hormone receptors. Biochem Soc Trans. 1997;25:1046-51.

142. Ivell R, Kimura T, Muller D, Augustin K, Abend N, Bathgate R, et al. The structure and regulation of the oxytocin receptor. Exp Physiol. 2001;86:289-96.

143. Rivenbark AG, O'Connor SM, Coleman WB. Molecular and cellular heterogeneity in breast cancer: challenges for personalized medicine. Am J Pathol. 2013;183:1113-24.

144. Manning M, Misicka A, Olma A, Bankowski K, Stoev S, Chini $\mathrm{B}$, et al. Oxytocin and vasopressin agonists and antagonists as research tools and potential therapeutics. J Neuroendocrinol. 2012;24:609-28.

145. Duerrauer L, Muratspahic E, Gattringer J, Keov P, Mendel HC, Pfleger KDG, et al. I8-arachnotocin-an arthropod-derived G protein-biased ligand of the human vasopressin V2 receptor. Sci Rep. 2019;9:19295.

146. Gruber CW, Muttenthaler M. Discovery of defense- and neuropeptides in social ants by genome-mining. PLOS ONE. 2012;7: e32559.

147. Dutertre S, Croker D, Daly NL, Andersson A, Muttenthaler M, Lumsden NG, et al. Conopressin-T from Conus tulipa reveals an antagonist switch in vasopressin-like peptides. J Biol Chem. 2008;283:7100-8.

148. Di Giglio MG, Muttenthaler M, Harpsoe K, Liutkeviciute Z, Keov P, Eder T, et al. Development of a human vasopressin V1areceptor antagonist from an evolutionary-related insect neuropeptide. Sci Rep. 2017;7:41002.

149. de Araujo AD, Mobli M, Castro J, Harrington AM, Vetter I, Dekan Z, et al. Selenoether oxytocin analogues have analgesic properties in a mouse model of chronic abdominal pain. Nat Commun. 2014;5:3165.

150. Busnelli M, Kleinau G, Muttenthaler M, Stoev S, Manning M, Bibic L, et al. Design and characterization of superpotent bivalent ligands targeting oxytocin receptor dimers via a channel-like structure. J Med Chem. 2016;59:7152-66.

151. Muttenthaler M, Andersson A, de Araujo AD, Dekan Z, Lewis RJ, Alewood PF. Modulating oxytocin activity and plasma stability by disulfide bond engineering. J Med Chem. 2010;53:8585-96.

152. Garona J, Pifano M, Pastrian MB, Gomez DE, Ripoll GV, Alonso DF. Addition of vasopressin synthetic analogue [V(4)Q (5)]dDAVP to standard chemotherapy enhances tumour growth inhibition and impairs metastatic spread in aggressive breast tumour models. Clin Exp Metastasis. 2016;33:589-600.

153. Benavente MA, Bianchi CP, Imperiale F, Aba MA. Antiproliferative effects of oxytocin and desmopressin on canine mammary cancer cells. Front Vet Sci. 2016;3:119. 